\title{
Presencia del héroe homérico en el Vaso François
}

\section{Presence of the Homeric Hero in the François Vase}

Artículo recibido el I3 de enero de 2016; devuelto para revisión el 20 de junio de 20I6; aceptado el 6 de diciembre de 20I6. http://dx.doi.org/IO.2220I/iie.I8703062e.20I7.I.259I.

Marysol Alhim Rodríguez

Maldonado

Líneas de investigación

Lines of research

Publicaciones más relevantes
Universidad Nacional Autónoma de México-Instituto de Investigaciones Filológicas, alhimrm@yahoo.es

Mitología grecolatina y arte griego antiguo; especialmente lo concerniente a la producción y pintura cerámicas.

Greco-Roman mythology and ancient Greek art; especially in relation to ceramic production and painting.

"Imagen de Ártemis en el Himno III de Calímaco", Nova Tellus. Anuario del Centro de Estudios Clásicos 31, núm. 2 (2013): I59-I84.

Resumen Con base en la teoría de la identidad cultural en el arte o teoría del arte como sistema cultural presento un análisis mítico-literario de las múltiples escenas pictóricas plasmadas en el complejo y controvertido Vaso François, las cuales relaciono temáticamente entre sí. A partir de allí, sugiero que deben estudiarse como un "todo" y en relación con la forma de la pieza en que se plasmaron y no como mitos aislados, postura encaminada a argumentar que el vaso en cuestión tiene una unidad iconográfica y formal, pensada de antemano, cuyo paradigma o hilo conductor es el héroe homérico y sus tópicos más significativos.

Palabras clave Vaso François; cerámica griega; héroe homérico; teoría de la identidad cultural; análisis mítico-literario; análisis iconográfico y formal; propuesta interpretativa.

Abstract Based on the cultural identity theory in art or art theory as a cultural system, the article presents a mythical-literary analysis of multiple and thematically related scenes depicted on the complex and controversial François Vase. In it, it is suggested that they should be studied as a "whole" and in relation to the form of the piece upon which they were painted, and not as isolated myths, the argument being that the vase in question has a preconceived iconographic and formal unity, whose paradigm or thread is the Homeric hero and the most significant themes related to him. 
DOI: http://dx.doi.org/10.22201/iie.18703062e.2017.1.2591

Keywords François Vase; Greek pottery; Homeric hero; cultural identity theory; mythical literary analysis; iconographic and formal analysis; interpretative approach. 
DOI: http://dx.doi.org/10.22201/iie.18703062e.2017.1.2591

\author{
MARYSOL ALHIM RODRÍGUEZ MALDONADO
}

INSTITUTO DE INVESTIGACIONES FILOLÓgICAS, UNAM

\title{
Presencia del héroe homérico en el Vaso François
}

U

na de las razones que impulsan y justifican este trabajo radica en que el Vaso François es notable por su manufactura, iconografía y composición, diferentes de las que poseen la mayoría de los vasos de su época y tipo, pues por lo general las piezas cerámicas de gran formato, en este caso las cráteras, al menos las de figuras negras elaboradas en el Ática y Corinto, estaban decoradas con imágenes grandes, por lo que no había oportunidad de distribuirlas en diversos frisos. Ésta es, creo yo, la principal importancia de esta pieza como objeto de estudio: rompe totalmente con los esquemas de formato y decoración del estilo al que pertenece por la numerosa cantidad de frisos y pequeñas figuras que cubren toda su superficie.

Lo anterior hace posible pensar que la variada y compleja decoración de esta crátera no fue producto del azar, sino de una cuidada estrategia discursiva dirigida a un fin específico, el cual, según trataré de mostrar en este trabajo, va más allá de simples fines decorativos.

El material existente hasta ahora sobre el tema puede ser sumamente extenso, desde innumerables menciones secundarias o sucintas de algún aspecto de la pieza, pasando por trabajos meramente descriptivos o enfocados a la historia arqueológica de la pieza (tal es el caso, por ejemplo, de Materiali per servire alla storia del Vaso François, Bolletino d'Arte; o Il Vaso François, de Antonio

I. Materiali per servire alla storia del Vaso François, Bolletino d'Arte. Serie Speciale LXII (I98I). Este volumen estuvo dedicado a recopilar y transmitir la bitácora con los registros arqueológicos y la correspondencia tanto privada como oficial que dan fe del descubrimiento de la pieza, así 
Minto), ${ }^{2}$ hasta investigaciones más complejas dedicadas al análisis de su simbolismo o de sus inscripciones (por ejemplo, "The Inscriptions on the François Vase", de Rudolf Wachter, ${ }^{3}$ por mencionar algunas). Debido a tal abundancia y a la imposibilidad de conseguir por el momento algunos textos, no tuve oportunidad de consultar todo el material existente, razón de más para advertir al lector que la búsqueda y comparación de algunas otras investigaciones, diversas a las aquí consultadas y que compartan o rechacen lo que a continuación expondré es una tarea ardua, que, por lo pronto, queda pendiente para un trabajo posterior, y que si bien algunas escenas o personajes de la pieza pudieran tener una lectura política, por el momento realizaré aquí una interpretación mítico-literaria.

Así pues, los objetivos perseguidos al analizar iconográfica y formalmente el Vaso François son: I) argumentar que el Vaso François no es una simple antología mítica seleccionada al azar, ya que posee unidad y sentido profundo, un paradigma o hilo conductor, y 2) que las escenas trazadas en él representan tópicos significativos del arquetipo del héroe homérico y están relacionados con la forma del vaso.

Para cumplir con estos objetivos y considerando de suma importancia que la cerámica griega antigua no era una simple decoración — sino que cada pieza se creó para un uso específico que se extendía desde el ámbito doméstico (contención y almacenamiento de líquidos y sólidos) y simposiaco, hasta el funerario, ritual, apotropaico, conmemorativo y de premiación, entre otros, ${ }^{4}$ y que tal utilidad no se circunscribía solamente al objeto cerámico como recipiente, sino que se extiende a las representaciones pictóricas que los recubrían (fueron, y aún siguen siendo, un medio para difundir y conservar imágenes de la vida cotidiana en sus más diversos aspectos así como escenas y narraciones gráficas que remitían a los mitos y leyendas acuñados por el imaginario griego)— realicé este

como los reportes técnicos de los múltiples procesos de restauración y conservación que experimentó la crátera hasta 1973.

2. Antonio Minto, $I l$ Vaso François (Florencia: Accademia Toscana di Scienze e Lettere La Colombaria, 1960). Exhaustiva descripción de los elementos figurativos que componen cada uno de los frisos. A mi parecer, se queda solamente en el campo descriptivo y no va más allá, aunque intenta establecer comparaciones entre las escenas del vaso y las que aparecen en otras piezas cerámicas.

3. Rudolf Wachter, "The Inscriptions on the François Vase", Museum Helveticum XCVIII (I99I): 86-II3. Breve artículo que realiza la recuperación y explicación de las numerosísimas inscripciones que aparecen en el vaso, es más bien un texto de carácter filológico que ayuda a la ubicación de los personajes que conforman la decoración de la pieza y a dilucidar algunos errores en las grafías.

4. Martin Robertson, El arte griego, trad. María Castro (Madrid: Alianza, 1985), 40. 
análisis con base en algunas ideas de Cliford Geertz y Joaquín Lomba Fuentes, ${ }^{5}$ enmarcadas dentro de la teoría de la identidad cultural en el arte o teoría del arte como sistema cultural, sustentada por diversas disciplinas como la sociología del arte, la historia del arte, la psicología del arte, la filosofía del arte y la estética.

Dicha teoría postula que la identidad cultural de determinado ente social encuentra su reflejo en sus creaciones artísticas, es decir que los medios de expresión del arte así como sus signos o elementos sígnicos y la concepción de la vida que la anima son inseparables, es decir, se hallan conectados. Así, expresiones como rituales, mitos y la organización social, entre otras, pueden crear las condiciones implicadas en determinada manifestación artística, y a su vez ésta refleja las concepciones fundamentales de la vida en sus más diversos aspectos. ${ }^{6}$

Es así como, en un primer momento, recurrí al análisis de la forma de la pieza, el significado y el tema de las imágenes plasmadas en el vaso y, posteriormente, tomé en cuenta la posible función de la crátera en el momento de su creación, así como las circunstancias no muy claras de su génesis y la relación con el contexto ideológico-cultural en el que se insertan sus cuadros compositivos, ya que, para conocer la cosmovisión que se refleja en esta obra (esquemas visuales) debemos conocer las ideas, la cultura y la sociedad del momento en el que se gestó (esquemas culturales).

Por último, cabe señalar la ineludible necesidad de consultar fuentes literarias de la antigüedad griega, pues son éstas las que conservan la tradición mítica en la que la mayoría de los ceramistas y pintores se basaron (unos más estrictamente que otros) para la creación del discurso decorativo de sus obras. Este punto es relevante, pues me permitió realizar una mancuerna interdisciplinaria entre historia del arte y filología.

\section{Breve descripción e historia del Vaso François}

El Vaso François es una crátera de volutas (vaso de simposio en el que se mezclaba el vino) de figuras negras, fechada entre 570 y 560 a. C. (finales del arcai-

5. Cliford Geertz, "El arte como sistema cultural”, en Cliford Geertz, Conocimiento local: ensayos sobre la interpretación de las culturas, trad. Alberto López (Barcelona: Paidós, I983), II7-I46; Joaquín Lomba Fuentes, Principios de filosofia del arte griego (Barcelona: Anthropos, 1987).

6. Geertz, "El arte como sistema cultural", II7-I46; Lomba, Principios de filosofía del arte griego, I3-I6; Eyedelkis Medina, Yenis Sánchez Matos, William del Rey y Yenlys Naung, "La identidad cultural en la obra de arte", en Contribuciones a las Ciencias Sociales, consultado el 3 de mayo de 20I2, www.eumed.net/rev/cccss/20/. 
DOI: http://dx.doi.org/10.22201/iie.18703062e.2017.1.2591

co maduro), realizada por el alfarero Ergótimos y el pintor Klitias. Por ser un vaso de grandes proporciones ( $66 \mathrm{~cm}$ de alto por 57 centímetros de ancho) probablemente fue modelado por piezas, y tal vez no sólo las asas y la base, sino el cuello y el cuerpo, ya que las partes mayores a $30 \mathrm{~cm}$ tendían a deformarse durante el horneado.

En I844, el arqueólogo florentino Alessandro François, durante una de sus campañas en una antigua necrópolis de Chiusi, descubrió, junto con algunas joyas y otras piezas cerámicas de menor valor, varios fragmentos del vaso dispersos en las diversas habitaciones, corredores y cámaras laterales de una tumba destinada a la nobleza. Después de largos y complicados procesos de restauración y de su esporádica permanencia en diversos museos y galerías, ${ }^{7}$ el Vaso François se encuentra, desde I880, en el Museo Arqueológico Nacional de Florencia.

El Vaso François resulta ser el único de su tipo que se conserva casi completo. Posee un formato grande para su época, pero con decoración en menor tamaño que el habitual, propia de la cerámica de pequeño formato; lo adornan 270 figurillas distribuidas en seis frisos (seis en el cuerpo y uno en el pie) y en seis ventanas o registros (tres en cada asa).

De un lado, en el cuello de la vasija, en el friso superior, está representado el géranos $^{8}$ de Teseo como vencedor del Minotauro; debajo, la lucha entre centauros y lapitas. Después, un único friso, de mayor anchura que los demás, recorre por ambos lados los hombros de la pieza, y presenta las bodas de Tetis y Peleo. En el vientre del vaso se aprecia el retorno de Hefesto al Olimpo (figs. I y 3 ).

En la cara opuesta de la pieza, en el cuello, el primer friso está decorado con la cacería del jabalí de Calidón y, en la parte inferior de éste, en el friso siguiente, se aprecian los juegos fúnebres en honor a Patroclo. En los hombros, como ya mencioné, continúa la escena nupcial. En el vientre de la pieza hay escenas del sitio de Troya (figs. 2 y 4).

El último friso del cuerpo del vaso, al igual que el friso con las bodas de Tetis y Peleo, rodea completamente la pieza, y lo conforman representaciones de animales (reales y fantásticos) y motivos florales. En la parte más baja del

7. John Davidson Beazley, The Development of Attic Black Figures (Berkeley/Los Angeles y Oxford: University of California Press, 1986), 24; Materiali per servire alla storia del Vaso François, 27-28; Minto, $I l$ Vaso François, 7.

8. Danza que consiste en evoluciones laberínticas que hacen alusión al recorrido que Teseo realizó en el laberinto siguiendo el hilo de Ariadna, su nombre deriva de la semejanza con el vuelo en hilera ondulante de las grullas (géranos, 'grulla')", al respecto véase Homero, La Ilíada, trad. Emilio Crespo Güemes (Madrid: Gredos, 199I), XVIII, 590 ss. 


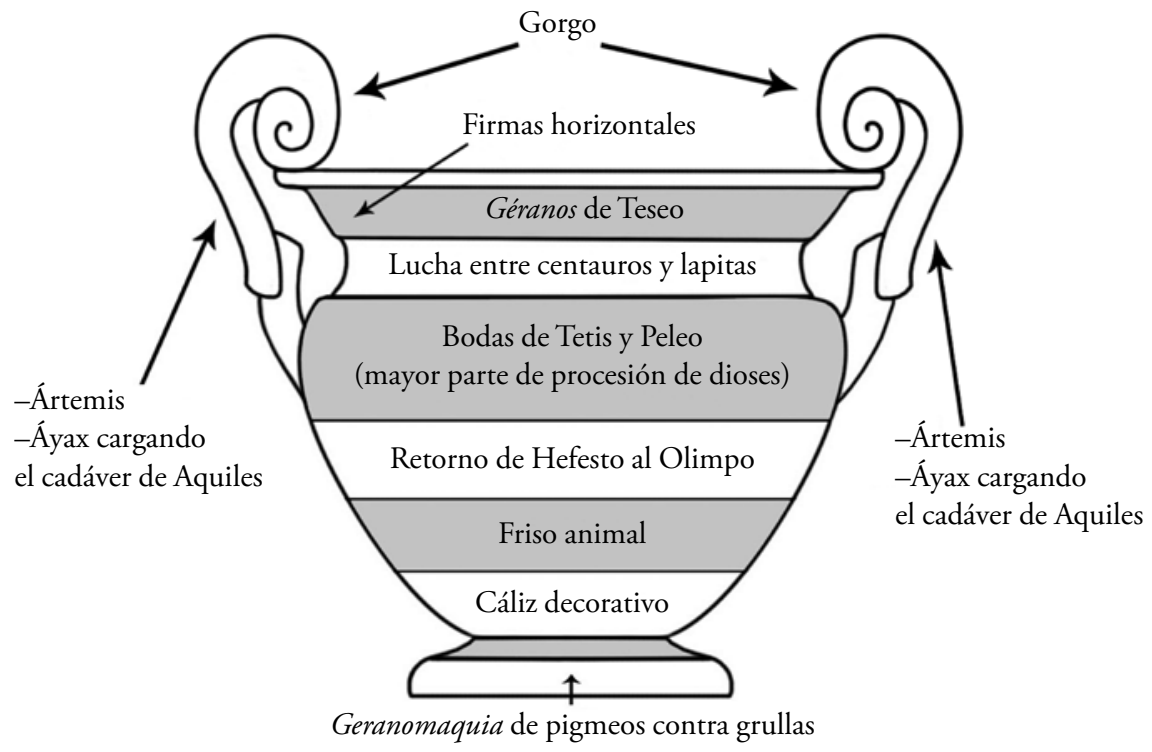

I. Frisos del lado “teseida”. Diagrama: Marleth Rodríguez.

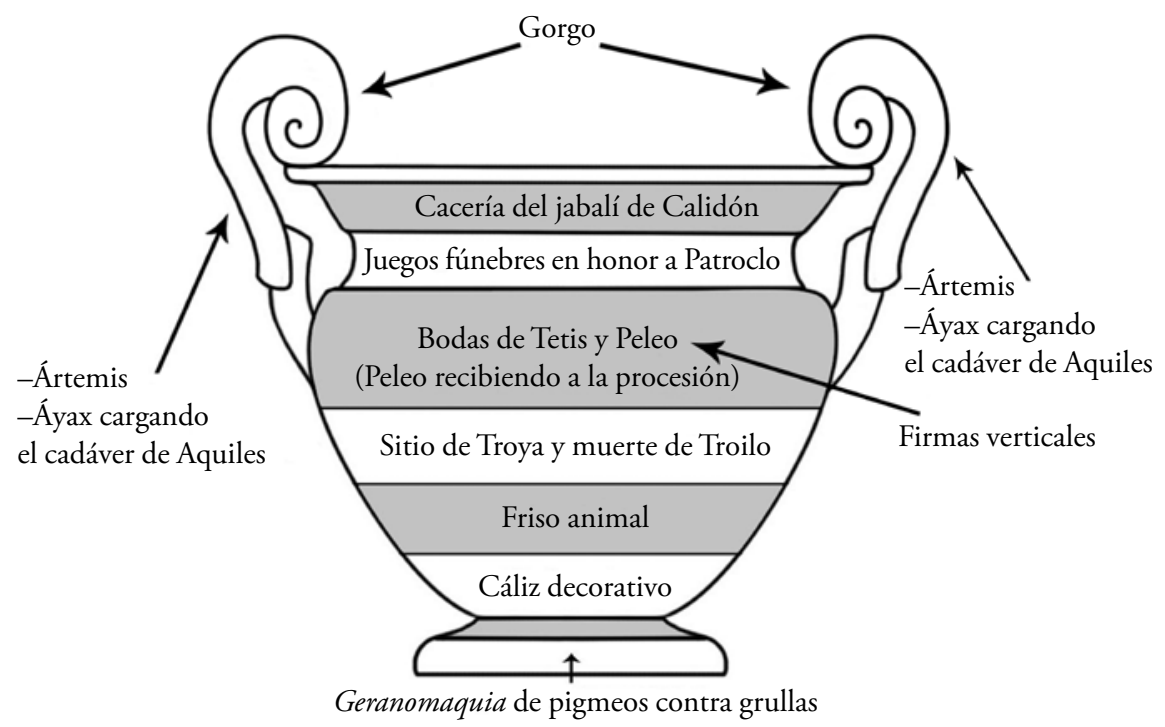

2. Frisos del lado “calidonio”. Diagrama: Marleth Rodríguez. 


\section{MARYSOL ALHIM RODRÍGUEZ MALDONADO}

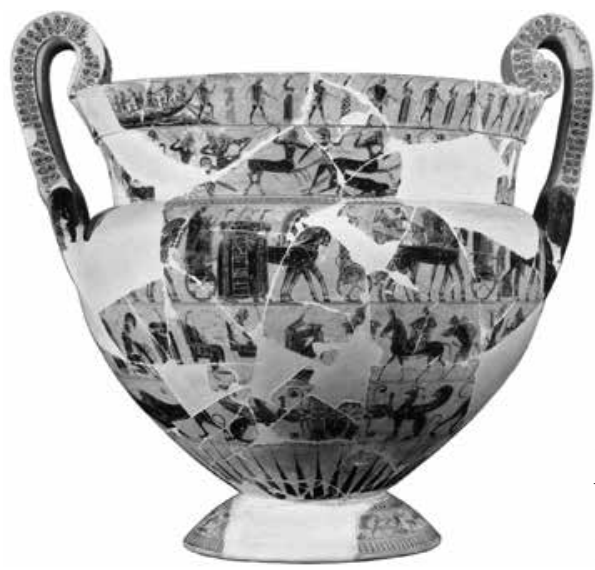

3. Lado "teseida", imagen tomada de Materiali per servire alla storia del Vaso François (vid supra n. I), I22. Universidad Libre de Berlín.

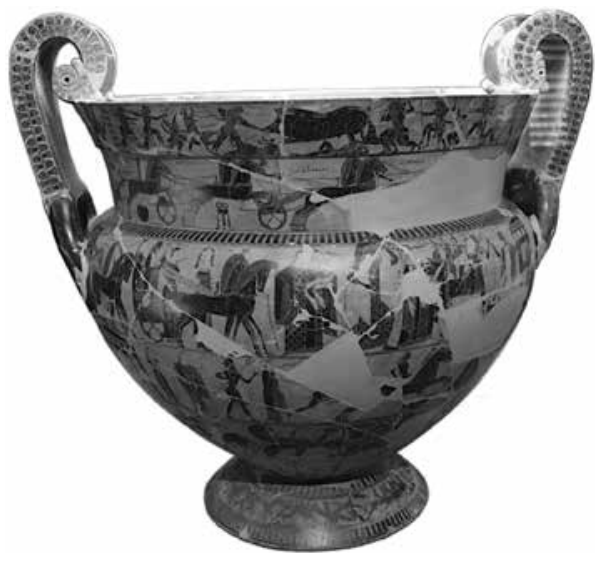

4. Lado "calidonio", imagen tomada de http://aemc4.wordpress.com/le-vasefrancois/, consultado el 2I de marzo de $201 \mathrm{I}$.

vaso y por ambos lados se encuentra la llamada decoración de cáliz; por último, un friso completo con la geranomaquia (lucha de los pigmeos contra las grullas) recorre todo el pie del vaso (figs. I-5). ${ }^{9}$ En cada una de las asas, decoradas en sus laterales con una doble línea de palmetas entrelazadas, hay tres registros decorativos o ventanas: en el primero, en la cara interior de la volu-

9. Para no exceder la extensión máxima requerida para la publicación de este texto, he decidido no incluir todas las imágenes utilizadas para realizar esta investigación, alrededor de 50, las cuales se obtuvieron de Materiali per servire alla storia del Vaso François, y de Minto, Il Vaso François. Las figuras i y 2, incluidas en este artículo, son diseño de Marleth Rodríguez, a quien agradezco profundamente su trabajo. 

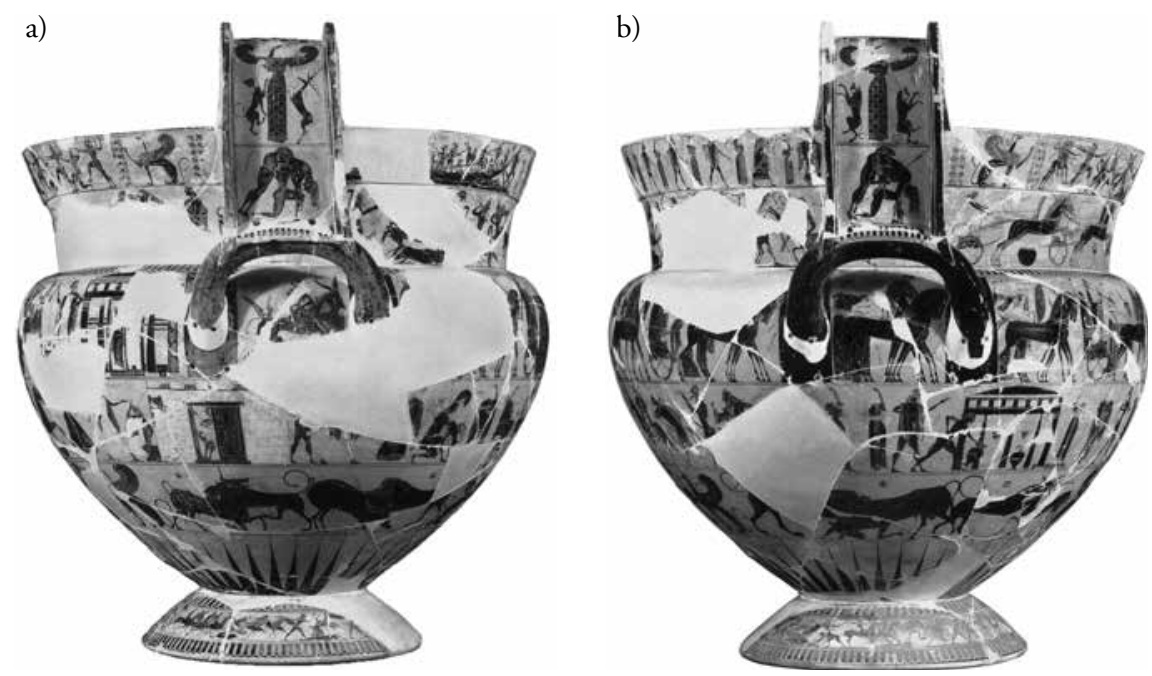

5 a) y b). Vistas laterales del vaso, imágenes tomadas de Materiali per servire alla storia del Vaso François (vid supra n. I), I20 y I23. Universidad Libre de Berlín.

ta, aparece Gorgo; en el segundo, una Pótnia Therón, y en el último, la imagen de Áyax cargando el cadáver de Aquiles (figs. 5-7).

La mayoría de las figuras están identificadas con inscripciones que las acompañan y, en el extremo superior izquierdo del friso con el regreso de Teseo y en el friso central con las bodas de Tetis y Peleo, se observan las firmas del alfarero y el pintor (figs. 8, 9 y IO). ${ }^{10}$ Las 130 inscripciones que presenta el vaso, que van desde firmas y nombres propios hasta nombres de objetos, son parte integral de la decoración de la pieza; algunas van de derecha a izquierda o viceversa según la dirección de la imagen, otras interactúan con las figuras, atravesándolas, rodeándolas y enmarcándolas, yendo más allá de la mera identificación de aquéllas, como se verá más adelante.

\section{¿Por dónde comenzar a interpretar el Vaso François?}

¿Dónde iniciar la lectura del vaso? ¿Cuál fue el motivo de su creación? ¿Su temática fue idea del ceramista o de algún cliente? ¿Fue una pieza realizada $e x$ Io. Ergótimos m’epoíesen (“Ergótimos me fabricó”) y Klitias m’égraphsen (“Klitias me pintó). 
DOI: http://dx.doi.org/10.22201/iie.18703062e.2017.1.2591

86 MARYSOL ALHIM RODRÍGUEZ MALDONADO

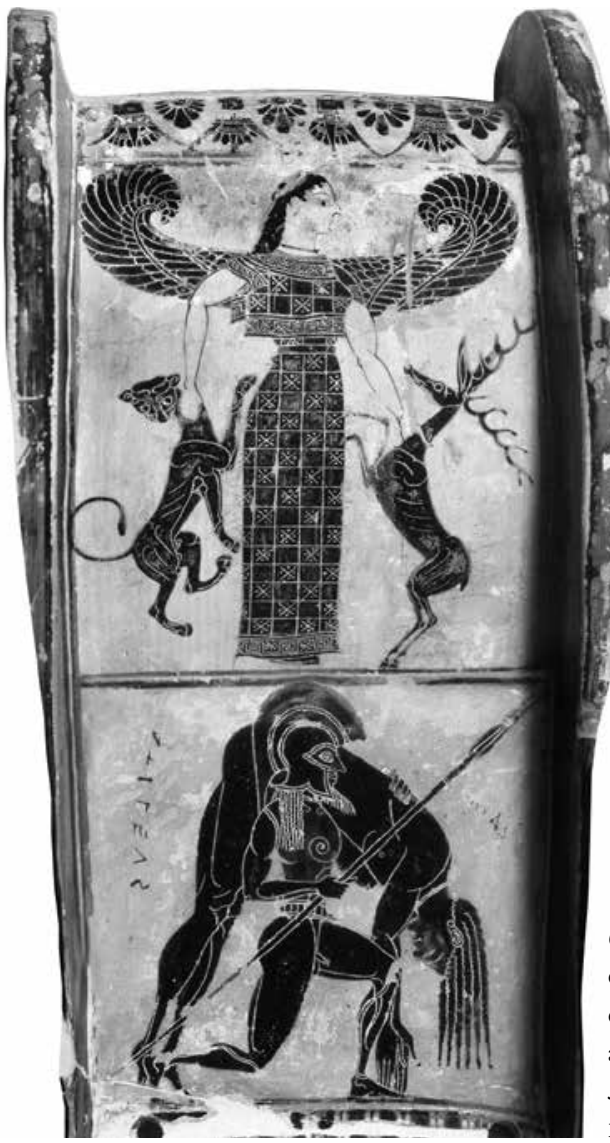

6. Exterior de una de las asas: Ártemis como Pótnia Théron y Áyax cargando el cadáver de Aquiles. Fragmento modificado a partir del de Materiali per servire alla storia del Vaso François (vid supra n. I), I49. Universidad Libre de Berlín.

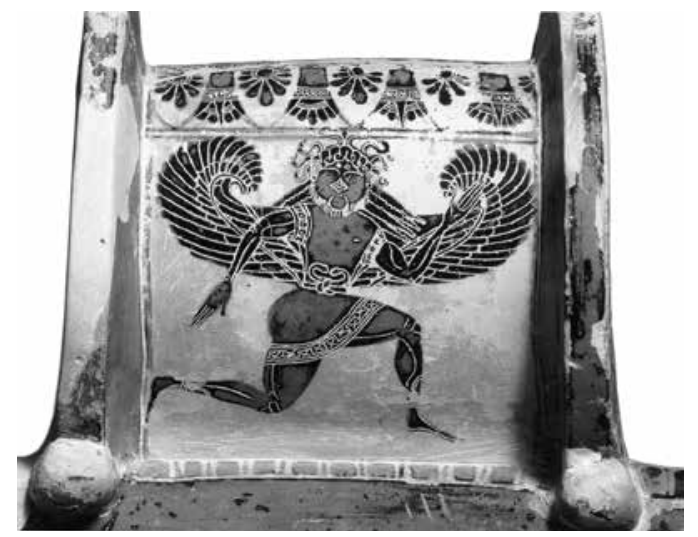

7. Exterior de una de las asas: Gorgo alada. Fragmento modificado a partir del de Materiali per servire alla storia del Vaso François (vid supra n. I), I52, fig. II3. Universidad Libre de Berlín. 


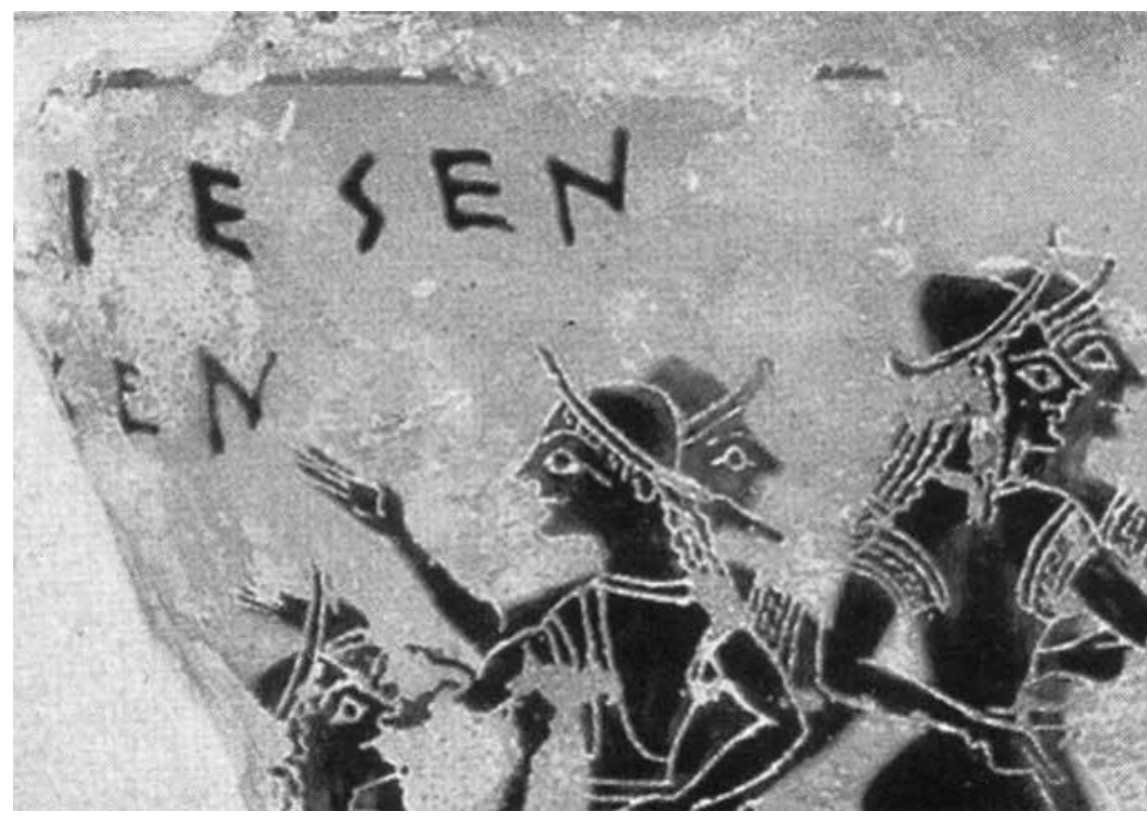

8. Firmas horizontales en el friso con el géranos de Teseo: Ergótimos m’epoíesen ("Ergótimos me fabricó") y Klitias mégraphsen ("Klitias me pintó”). Fragmento tomado de Materiali per servire alla storia del Vaso François (vid supra n. I), I8I, fig. I6o. Universidad Libre de Berlín.

professo para exportación? ¿Existe una relación entre su temática y la tipología y función de la pieza? ¿Qué lado de ésta puede considerarse como el anverso y cuál el reverso? ¿Cuál es la secuencia correcta de lectura de las escenas pintadas en ella? ¿Los frisos de cada lado pueden y deben leerse en un orden descendente? ¿Existe una relación entre los frisos de ambos lados? Éstas son algunas de las primeras interrogantes que surgen al observar que la totalidad de la crátera está cubierta de numerosísimas figurillas que participan en variados episodios míticos superpuestos, y para comenzar a darles respuesta se deben atender ciertos aspectos relativos al contexto y a la forma de la pieza:

\section{Pautas contextuales}

Por ser el Vaso François tan complejo y único en su tipo, y por no haber ninguna fuente literaria antigua que hable de su historia, esta pieza cerámica resulta 

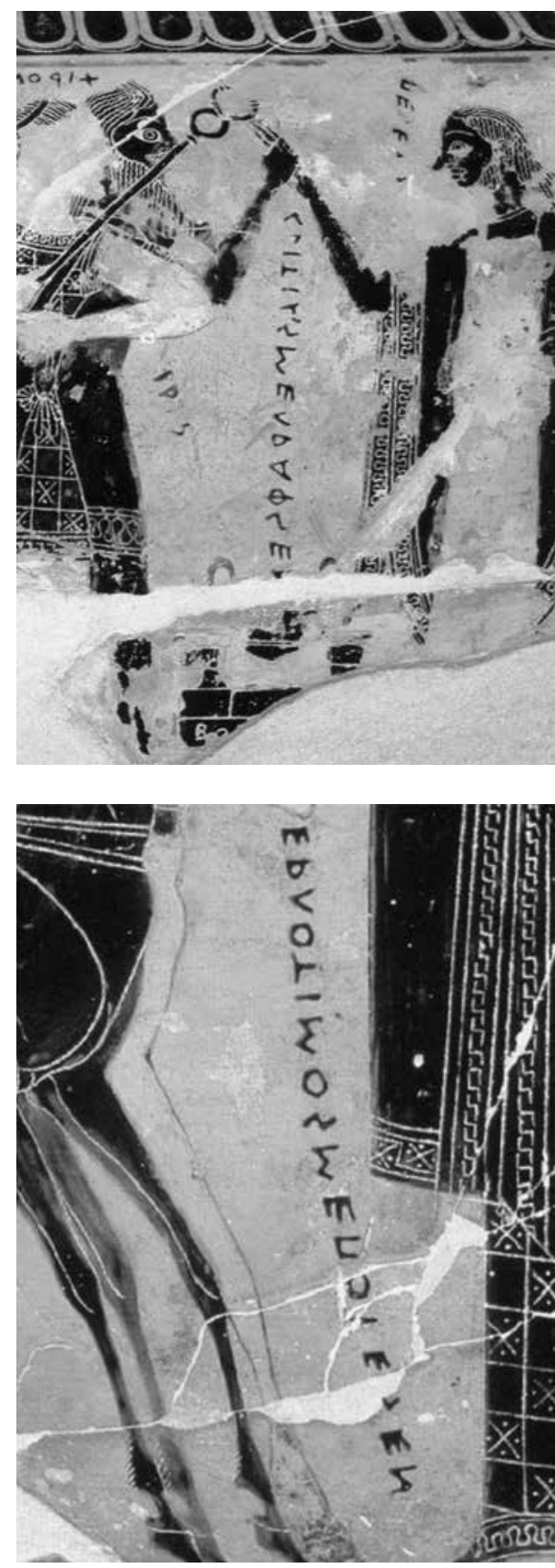

9. Firma vertical de Klitias en el friso con las bodas de Tetis y Peleo: Klitias m'égraphsen ("Klitias me pintó").

Fragmento tomado de Materiali per servire alla storia del Vaso François (vid supra n. I), I66, fig. I33. Universidad Libre de Berlín.
Io. Firma vertical de Ergótimos en el friso con las bodas de Tetis y Peleo: Ergótimos m’epoiesen ("Ergótimos me fabricó"). Imagen tomada de Materiali per servire alla storia del Vaso François (vid supra n. I), I87, fig. 20I. Universidad Libre de Berlín. 
misteriosa. No es seguro que haya sido creado por encargo de un cliente específico, ni se puede saber si las escenas plasmadas en él las estableció enteramente el pintor o si hubo alguna intervención clientelar en la elección de los

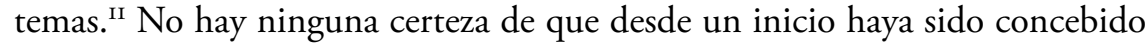
como una ofrenda mortuoria, pues su lugar de descubrimiento no es motivo suficiente para aseverarlo, o incluso de que se pensara como un regalo de bodas, aunque el ancho y llamativo friso nupcial que rodea sus hombros pueda sugerirlo. Tampoco se sabe nada de su uso antes de haber sido colocado en la necrópolis etrusca; aunque, por su tipología, con seguridad se empleó en un contexto simposiaco, colocado al centro de un banquete para proveer de vino a los comensales.

Sin embargo, por su lugar de fabricación (el Ática), su datación (periodo arcaico) y su lugar de descubrimiento (Chiusi), es evidente que lo destinaron a la exportación, fin muy común en la época, pues, como es bien sabido, el comercio de vasos áticos adquirió un enorme desarrollo a partir del siglo vi a. C. y a lo largo del siglo v. ${ }^{12}$

Este auge de la exportación de vasos de figuras negras se debió al impulso del artesanado, especialmente de los ceramistas, durante la época de la tiranía pisistrátida (56I-5IO a. C.). Es importante destacar aquí el control que los tiranos ejercieron sobre el trabajo de los artesanos y el hecho de que Pisístrato y sus descendientes utilizaran algunas de las imágenes plasmadas en los vasos como medio de propaganda política. ${ }^{\mathrm{I3}}$

Por esta razón sería posible pensar que detrás del Vaso François pueda existir una clara referencia a los aportes político-sociales de la tiranía a la polis ateniense o una alusión a alguno de los principales actores políticos o sucesos de la época. Ahora bien, si atendemos a que durante la tiranía se reguló la recitación oficial de La Ilíada y La Odisea en distintos festivales y a que, por ello, floreció la figura del héroe épico, vinculado con el origen y desarrollo de la ciudad, y las hazañas heroicas del pasado homérico se volvieron muy familiares

II. Beazley apunta que los vasos destinados a la exportación muchas veces respondían a las preferencias de los clientes, pero que el gusto por determinadas formas y temas por lo general lo imponían los exportadores (apud L. J. Balmaseda y Ricardo Olmos, "Mito y figuración en la cerámica ática de época clásica. El último periodo arcaico", Cuadernos de Filología Clásica XVII [I98I-I982]: II2).

I2. Balmaseda, "Mito y figuración en la cerámica ática de época clásica”, II2.

I3. John Boardman, Athenian Black Figure Vases (Londres: Thames and Hudson, 1974), II2; "Herakles, Peisistratos and Sons", Revue Archéologique I (1972): 57-72. 
DOI: http://dx.doi.org/10.22201/iie.18703062e.2017.1.2591

para los atenienses, quienes, en un acto de añoranza, las plasmaron en un sinnúmero de vasos, ${ }^{\mathrm{I}}$ se podría estar tentado a descalificar la hipótesis interpretativa anterior de corte político y a aseverar de manera tajante que este objeto tiene una lectura exclusivamente mítica o literaria.

En vista de esta problemática y de que la pieza objeto de este estudio es tan compleja, tan rica en imágenes y temáticas, y creada en un contexto importantísimo de evolución y remodelación artística, social, religiosa y política, considero que sería un tremendo error pensar en la existencia de una única y absoluta interpretación que la explicara. En mi opinión, puede haber distintas interpretaciones válidas de la pieza, dependiendo de si se enfocan en estudiar ya sea su aspecto político, social, mítico-literario, o incluso aspectos combinados, y si se quiere verla como un todo, o de manera fragmentada.

En esta ocasión me centraré en examinar iconográfica y formalmente el Vaso François mediante la lectura que retoma la épica homérica, en específico la figura arquetípica del héroe, aunque no dejaré de mencionar, de manera secundaria, ciertos valores de importancia que pudieran tener las figuras míticas representadas para la sociedad ateniense del siglo vi, como se verá en el caso de Teseo y Hefesto.

\section{Pautas formales}

Antes de comenzar el análisis del vaso, debo establecer si existe un lado "A" y un lado "B", así como por cuál friso iniciaré la lectura; para ello tomaré en cuenta varias características: I) la forma y función de la pieza, 2) el peso visual y 3) la colocación de las firmas del alfarero y del pintor.

I) Forma y función de la pieza: un aspecto sumamente importante de una obra de arte es su forma. María Nieves Zedeño, en un estudio de la forma y contenido enfocado en piezas cerámicas, menciona que la forma, en sentido general, es

la calidad de las relaciones de organización de los elementos y procesos que integran el contenido, o la manera cómo éste se estructura [...] todas las características formales

I4. Claude Mossé, La tyrannie dans la Grèce Antique (París: Presses Universitaires de France, 2004), 7I; Balmaseda, "Mito y figuración en la cerámica ática de época clásica”, II4-I22. 
fenoménicas observables en la cerámica, las cuales se pueden agrupar por categorías formales: forma básica de la pieza, estilo (formal-decorativo) y propiedades físicas derivadas de su manufactura $[\ldots]$ ordenamiento de los materiales a partir de las dimensiones de geometría y la proporción y de patrones funcionales socialmente aceptados, e inclusive estandarizados dentro de cierto grupo o para cierta época. ${ }^{15}$

En cuanto a la función cerámica, la misma autora dice que ésta puede inferirse fundamentalmente a partir de sus características formales, propiedades físicas, forma básica, asociaciones contextuales, huellas de uso, estilo decorativo, entre otros, y se divide en primaria y secundaria. Para conocer la función primaria de las piezas cerámicas es necesario considerar la asociación contextual de las formas básicas. Dentro de las unidades de descripción es importante tomar en cuenta las dimensiones de geometría y proporción; una misma forma reproducida en diferentes proporciones pudo cumplir funciones distintas. $\mathrm{La}$ función secundaria puede inferirse, además de su asociación contextual, por medio de huellas de uso, si están presentes. Por ejemplo, cuando vasijas que evidentemente han cumplido una función doméstica (inferida por huellas de uso o por asociación de las mismas formas con contextos domésticos) se encuentran como ofrendas funerarias, podría decirse que su función secundaria fue haber sido parte de una ofrenda, aunque originalmente hubieran sido producidas para uso doméstico. ${ }^{16}$

Con base en estas definiciones, presento las siguientes tablas en cuanto a la forma y función del Vaso François:

\section{FORMA}

Forma básica Crátera de volutas, pues, según la tipología, sus asas, que sobresalen de la boca o borde, forman volutas.

Características específicas de la forma Es más ancha, especialmente en los hombros, y redonda que otras cráteras de volutas, porque quizá el alfarero tomó como modelo y reelaboró una crátera de metal hoy perdida semejante a la crátera de bronce con tapa-criba de Vix, I.64 m de altura, mediados del siglo VI. ${ }^{17}$

Dimensiones y proporciones Más grande de lo normal, $66 \times 57 \mathrm{~cm}$.

I5. María Nieves Zedeño, "La relación forma-contenido en la clasificación cerámica”, Boletín de Antropología Cerámica, núm. II (1985): 19-26, esp. 2I.

16. Zedeño, "La relación forma-contenido en la clasificación cerámica", 25-26.

17. Robertson, El arte griego, 75 y 8I, fig. 58. 
Materia Arcilla roja ateniense (por la presencia de ocre rojo u óxido férrico). ${ }^{18}$

Técnica de manufactura Modelado por partes, ya que las piezas mayores a $30 \mathrm{~cm}$ tendían a deformarse durante el horneado.

Técnica decorativa De manera general:

Figuras bosquejadas con incisiones antes del secado de la pieza.

Figuras coloreadas e inscripciones dibujadas (pintadas sin incisión) antes del horneado con pintura-barniz de arcilla no porosa, que al final de la cocción se vuelve de color negro (el óxido de hierro se convierte en óxido de hierro magnético negro u óxido ferroso negro). ${ }^{19}$

Características específicas de la decoración Numerosas figurillas (270), propias de la cerámica de pequeño formato, pero no de piezas grandes.

Organización de la decoración Decoración organizada en múltiples frisos superpuestos, no muy comunes en piezas grandes.

Dos frisos continuos que le brindan a la pieza un carácter cíclico y unitario. Un friso más ancho que los demás (en los hombros).

\section{FUNCIÓN}

Primaria Por el tipo de vaso (crátera), seguramente cumplió con una función simposiaca, de banquete.

Por sus proporciones y características decorativas, así como por su lugar de descubrimiento (Chiusi), quiza se destinó desde un inicio a la exportación y no al comercio local.

Como la mayoría de las piezas cerámicas decoradas con escenas míticas o de la vida cotidiana, fue un medio de transmisión mítico-cultural, de Atenas a Etruria, y de allí seguramente a Roma.

Secundaria Por su lugar de descubrimiento (tumba), destinada como ofrenda funeraria.

Aunque no es seguro, no se descarta la posibilidad de que fuese un regalo $\mathrm{u}$ objeto conmemorativo de boda.

2) Peso visual: Como lo mencioné, la escena de la boda de Tetis y Peleo recorre por ambos lados los hombros del vaso y, a diferencia de los demás frisos, es de mayores proporciones, razones por las que en él recae el peso visual de la deco-

I8. La procedencia de las arcillas se puede identificar por su color; una arcilla roja encendida, seguramente proviene de Atenas, mientras que una arcilla con color más apagado, pálido, anaranjada o amarilla-verdosa, es típica de la zona de Corinto.

19. Gisela Marie Augusta Richter, El arte griego. Una revisión de las artes visuales de la antigua Grecia, trad. Rosa Portell (Barcelona: Destino, 1980), 317-319. 
ración. En este friso se observa un cortejo de dioses, encabezado muy acertada y conscientemente por Quirón e Iris, que se dirige al oikos ("casa”) de los recién casados para entregar ofrendas nupciales, entre las que se reconocen varias liebres y un ánfora con vino. Peleo, el novio, sale a recibir la procesión, mientras la novia, Tetis, permanece en actitud sedente dentro de su casa. Aparentemente el friso está dividido en dos partes: de un lado se ve la casa de los novios y los dioses que encabezan la procesión; del otro, el resto de los dioses. Sin duda es más llamativa la parte donde aparecen las figuras de los novios y el inicio del cortejo, pues éstos sintetizan en su totalidad o hacen referencia directa al mito, no se necesita observar el resto del cortejo para saber de qué episodio se trata. Por ello podría pensarse que el lado que muestra dicha parte fuera identificado como "A" (frisos: jabalí de Calidón; juegos fúnebres en honor a Patroclo; bodas de Tetis y Peleo, segmento de recibimiento; sitio de Troya) (figs. 2 y 4), pero eso está por verse.

3) Colocación de las firmas del alfarero y del pintor: las firmas de los creadores del vaso aparecen en dos ocasiones: la primera en el friso de las bodas de Tetis y Peleo, del lado donde se observa a los novios; la segunda, en la cara opuesta de la pieza, en el ángulo superior izquierdo del primer friso, que ostenta la escena de la llegada de Teseo a Delos. Entonces, ¿qué importancia tenían las firmas cerámicas? Todo esto ¿qué nos dice en el caso del Vaso François?

En el siglo vir a. C., junto al florecimiento de la cerámica ática de figuras negras, los ceramistas áticos comenzaron a firmar sus obras, quizá como una marca de identidad o propiedad. Las primeras firmas eran de tipo "nombre del ceramista + m’epoíesen (me fabricó)" (pintadas y no incisas como después se hará), e indican que un mismo artesano era responsable tanto de tornear el vaso y cocerlo como de decorarlo. Posteriormente, a mediados del siglo vir a. C., aparecieron las firmas de tipo "nombre + m’égraphsen (me dibujó/decoró/escribió)", quizá originadas por la creciente complejidad de los dibujos realizados y tal vez por el deseo de diferenciar la labor del pintor de la del ceramista (640-570). ${ }^{20}$

Para el año 570 aparecen juntas por vez primera las firmas de un alfarero y un pintor, justamente en el Vaso François, particularidad registrada en contadas ocasiones posteriores. Villard propone que los autores quisieron con ello no hacer patente la oposición entre el trabajo de cada uno, sino subrayar su colaboración. Más adelante (570-520), en la cerámica de figuras negras, los

20. François Villard, "L'Apparition de la signature des peintres sur les vases grecs", Revue Études Grecques, II5 (2002): 778-779, 782. 
DOI: http://dx.doi.org/10.22201/iie.18703062e.2017.1.2591

pintores prefieren utilizar epoiesen (inciso y coloreado), para firmar sus obras en vez de égraphsen. ${ }^{21}$

No es ésta una ocasión para ahondar en los tipos y usos de las inscripciones y firmas en las piezas cerámicas, baste con acotar por el momento que es posible que las firmas obedecieran al impulso del artesanado en la época y a cuestiones comerciales, y que existiesen inscripciones que, además de indicar qué personajes aparecían en las representaciones, o de consignar los nombres de los artesanos, o de manifestar una dedicatoria a una persona en específico, entre otros, podían tener un valor decorativo y reforzar la dinámica de la imagen. Con base en esto, y tomando en cuenta que la crátera o Vaso François se encontró en una tumba etrusca, y que lo más probable es que la nobleza del lugar no pudiera entender ni las firmas ni las grafías nominativas plasmadas en ella, me atrevo a proponer que, en este vaso, además de posiblemente expresar la mancuerna entre alfarero y pintor o el gusto clientelar, las firmas pudieran funcionar como un elemento más de la imagen para reforzarla o como un indicio para fijar la atención en alguno de sus elementos. Así, las firmas horizontales (fig. 8) que aparecen en el ángulo izquierdo del friso con el géranos de Teseo acompañan y enfatizan la horizontalidad de la nave representada, del oleaje marino y del joven que nada hacia la orilla de la isla, contrastando con la verticalidad de los cuerpos de los marinos, así como con las diagonales formadas por la inclinación de los torsos y las cabezas de algunos de los danzantes que se encuentran en la isla, líneas reproducidas por las respectivas inscripciones con sus nombres. Por otro lado, en el caso del ancho friso con las bodas de Tetis y Peleo, la firma vertical de Klitias (fig. 9), que parece salir del cántaro colocado sobre el altar nupcial (bomós) y termina debajo del ángulo formado por las manos entrelazadas de Peleo y Quirón, enfatiza, por un lado, la temática de la escena: el recibimiento del cortejo de dioses para asistir a la celebración matrimonial, y, por el otro, la posterior relación de Peleo y el centauro, pues éste será quien adiestre al hijo de aquél en las artes bélicas. Por su parte, la firma de Ergótimo (fig. Io), en ese mismo friso, entre las Horas y la musa Calíope, llama la atención sobre éstas. Las primeras, las Horas, según estudios de L. M. L'HommeWéry, son divinidades áticas honradas en las fiestas Dionisias en el altar de Dioniso Orthos, pues, en el siglo vı, época de fabricación del Vaso François, se consideraban no sólo como deidades agrarias, sino también como diosas cívicas que mantenían en orden y armonía la ciudad, de ahí la importancia de llamar la

2I. Villard, "L'apparition de la signature des peintres sur les vases grecs", 780 y 782. 
atención sobre ellas mediante la firma del pintor. La segunda, Calíope, se enfatizó con una inscripción probablemente por tener una importancia para amenizar el banquete de bodas; mientras Dioniso creará entusiasmo y éxtasis divino mediante el vino, ella lo hará por medio de la música. ${ }^{22}$

Ya establecido entonces el carácter decorativo y enfático de las firmas del Vaso François, puede pensarse que la aparición de algunas de ellas en el friso con mayor impacto visual, específicamente en el lado con los personajes más representativos del discurso (Tetis y Peleo), refuerza la hipótesis de que dicho lado podría ser denominado "A" (frisos: jabalí de Calidón; juegos fúnebres en honor a Patroclo; bodas de Tetis y Peleo, segmento de recibimiento; sitio de Troya). Sin embargo, si la primera mitad del friso con las bodas da la pauta para la designación del anverso y reverso, ¿por qué aparecen de nuevo las firmas del alfarero y pintor en el lado opuesto y en un friso de menor peso visual?

En efecto, el friso con el géranos de Teseo posee menor peso visual que el de las bodas, pero, en el contexto ateniense, lugar de la fabricación de la pieza de estudio, esta narración, que alude a una de las primeras hazañas de Teseo después de ser reconocido como hijo del rey del Ática, presenta en sus versiones gráficas o literarias mayor peso mítico-social, como se verá a continuación.

Hay que recordar que Teseo es el héroe del Ática por antonomasia, equiparable, por tanto, al valor de Heracles para los dorios. ${ }^{23}$ Según el mito, Teseo no sólo abolió el antiguo tributo de jóvenes que Minos exigía para su sacrificio cada nueve años, sino que fue una figura con grandes repercusiones sociopolíticas en la formación de la ciudad ateniense. Su victoria sobre Creta representaría la obtención de la hegemonía de Atenas sobre el ámbito insular del Egeo. En la tradición mítica ateniense, cuando Teseo asumió el poder en el Ática, su primer acto como gobernante fue realizar el sinecismo, es decir, reunir en una sola ciudad a los habitantes que se encontraban diseminados en el campo; además, nombró a Atenas capital del Estado así constituido; la dotó de los edificios políticos esenciales, como el Pritaneo y la Bulé; instituyó las Panateneas, fiestas que simbolizaban la unidad política del Ática; acunó monedas; dividió la sociedad en tres clases: nobles, artesanos y agricultores, e instauró, en sus líneas generales, el funcionamiento de la democracia. ${ }^{24}$

22. L. M. L'Homme-Wéry, "L'Athènes de Solon sur le Vase François", Kernos in (2006): 273-274.

23. Apolodoro, Biblioteca, II, 3-7; Robert Graves, Los mitos griegos, t. I, trad. Luis Echávarri (Buenos Aires: Losada, 200I), 436.

24. Plutarco, Vida de Teseo, en Plutarco, Vidas paralelas I, trad. Aurelio Pérez Jiménez (Madrid: Gredos, 1985), II, XXIV, XXV. 
DOI: http://dx.doi.org/10.22201/iie.18703062e.2017.1.2591

96 MARYSOL ALHIM RODRÍGUEZ MALDONADO

Con todo lo anterior, ¿cómo saber entonces cuál es el friso de mayor importancia y en el que es posible basarse para asignar el lado "A" y el lado "B" de la pieza? ¿'Teseo llegando a Delos o Peleo recibiendo la procesión nupcial? ¿Habrá que darle preferencia al peso visual o al peso simbólico-social? Ante esta aparente confusión, propongo lo siguiente:

I. Olvidar el convencionalismo de nombrar a los lados de la pieza como "A" y "B", "I" y " 2 " o "anverso" y "reverso", pues esto proporciona una idea de predominancia de un lado sobre otro, de que deben examinarse primero los frisos de una cara y luego los de la otra, y es parte de mi hipótesis aquí presentada ver el Vaso François como un todo unitario (unidad ya de por sí sugerida por el enorme friso de las bodas que "recorre", "une", toda la circunferencia del vaso); ver los frisos como una trama narrativa con continuidad, vinculados entre sí en la medida de lo posible, y no analizarlos de manera aislada. Luego entonces, dada la necesidad de identificarlos de alguna manera, y siendo "imposible" encasillar los temas míticos de cada lado por ciclos heroicos ("teseida" u "homérico"), sugiero nombrar a cada lado con base en la temática del primer friso que presentan en orden descendente; así pues, serían, respectivamente, "lado teseida" (frisos: géranos de Teseo; centauros contra lapitas; bodas de Tetis y Peleo, segmento procesional; Hefesto regresando al Olimpo) y "lado calidonio" (frisos: jabalí de Calidón; juegos fúnebres en honor a Patroclo; bodas de Tetis y Peleo, segmento de recibimiento; sitio de Troya), sin que esto implique, claro, preeminencia de dichos frisos sobre los demás o un orden por lado respecto a un ciclo mítico determinado, es sólo por cuestiones identificativas.

2. Atender a la forma globular de la crátera, que sugiere un carácter de totalidad/unidad (que es justo el que quiero atribuir entre sí a sus representaciones pictóricas) y de principio-fin, muy acorde con el carácter cíclico de vida-muerte de los mitos heroicos representados.

3. Dar mayor importancia a la parte más prominente del vaso (hombros), que llama la atención no sólo por sus proporciones físicas, sino también por las dimensiones decorativas que presenta (friso nupcial).

4. Por ser necesario un punto específico de partida para comenzar el análisis, considerar a los frisos con firmas (bodas de Tetis y Pelo/Teseo en Delos) — que son a su vez, como ya mencioné, los de mayor peso visual y simbólico, respectivamente- como candidatos a ello. 
5. Comenzar el análisis por el friso nupcial, pues, además de ostentar las firmas del alfarero y pintor, que refuerzan la imagen, en él recae el mayor peso visual y, como se verá más adelante, puede aludir al origen noble/divino del modelo heroico homérico. También es importante considerarlo como una unidad, no como un friso dividido, pues obviamente la división de la escena en dos no obedece a una deliberada diferenciación, sino tan sólo a cuestiones de espacio y a querer que el friso abarcara, rodeara, toda la pieza, en un intento acaso de conferirle unidad, totalidad.

6. Continuar el análisis con el friso teseida, pues las firmas en él y el simbolismo ático del mito lo señalan como el segundo en importancia.

7. Realizar el análisis asociando de manera paralela los frisos de uno y otro lado, y en orden descendente.

Una vez realizadas todas estas acotaciones, pasaré al análisis de la pieza en cuestión.

\section{El modelo heroico homérico}

La mitología griega está repleta de "héroes" cuyos rasgos (características físicas y morales particulares) y gestas a lo largo de las diferentes épocas de la literatura en la Grecia antigua o en los diferentes mitos y leyendas no siempre fueron los mismos. Por ejemplo, no es lo mismo un héroe épico que un héroe trágico, y dentro de la épica, las características pueden diferir de un personaje a otro.

Es imprescindible tener en cuenta que las diversas figuras heroicas griegas son tan complejas y diferentes entre sí, incluso si pertenecen a un mismo mito o leyenda, que no se pueden clasificar en una tipología única y rígida, y podría resultar difícil estudiarlas de manera grupal o a todas desde la misma disciplina, ya sea filología, psicología, antropología, historia de las religiones, entre otras. Como bien argumenta Carlos Bermejo Barrera, cada héroe debe estudiarse desde su individualidad, pues tiene peculiaridades específicas. ${ }^{25}$

Para este estudio me concentré en la épica griega, que comenzó de manera oral en la época micénica y tuvo su mayor esplendor en el siglo viII con Homero. Este género literario centra sus motivos en las luchas heroicas de la 
DOI: http://dx.doi.org/10.22201/iie.18703062e.2017.1.2591

Edad de Bronce, según el mito, la etapa más antigua, bella y gloriosa de la humanidad.

Para Walter Burkert un héroe épico es todo aquel guerrero cuya fama es cantada por los bardos, como sucede con todas las figuras homéricas, a diferencia del sentido que se le da en épocas posteriores, cuando un héroe era un difunto al que, debido a sus hazañas y actos sublimes y dignos de imitar, se le rendía culto esperando obtener su protección o algún beneficio. ${ }^{26}$

En la épica griega destaca la figura del héroe homérico, que incluye principalmente aquellos personajes que lucharon en Troya (siglo XII o XIII a. C.) y que, muertos en batalla o por otras causas, moran en el Hades o en la Isla de los Bienaventurados. El héroe homérico era o bien un semidiós (hemitheos), hijo de un dios y un mortal, que se situaba en un rango intermedio entre dioses y mortales, ${ }^{27}$ la mayoría de las veces de cuna noble, o un rey o un guerrero. En La Ilíada y en La Odisea, los héroes son seres superiores física y moralmente, cuya conducta y carácter se determina a partir del kléos, "la fama" (lograda en la guerra por decisión propia), la timé, "estima" u "honor" (resultado de la fama y simbolizado en cosas materiales o botín de guerra, y que demuestra el valor), y la areté, "excelencia o virtud político-guerrera y/o moral". ${ }^{28}$ Además, se les califica como prómacho $i,{ }^{29}$ es decir, que marchan en primera línea durante el combate, o se dice de ellos que prótoisi máchesthai, "pelean en primera fila", y que suelen combatir de manera individual, por lo que además resultan en extremo valerosos. ${ }^{30}$

Así, a grandes rasgos, el héroe homérico es áristos (perteneciente a una casa ilustre, noble, cuya ascendencia remonta a los dioses), agathós (un guerrero con alta areté, es decir, virtud, valor y capacidad en batalla, que en tiempos de guerra obtiene el éxito y, por ello, en tiempos de paz disfruta de las ventajas sociales inherentes a su condición) y kalós (en sentido moral, bueno, noble, honorable, virtuoso). ${ }^{31}$

26. Walter Burkert, Religión griega arcaica y clásica, trad. Helena Bernabé (Madrid: Abada, 2007), 275.

27. Homero, La Iliada, II, 478; XII, 23; XIII, 5I8; XVI, I73, I79; XXIV, 258.

28. Elsa Margarita Camacho, El concepto del héroe en la poesía épica y en la tragedia griegas (México: Universidad Autónoma Metropolitana-Azcapotzalco-Coordinación de Extensión Universitaria, 198I), I3-I4; Francisco Rodríguez Adrados y Luis Gil Fernández, Introducción a Homero (Barcelona: Labor/Punto Omega, 1984), 4I.

29. Homero, La Ilíada, XII, 3 I2.

30. Homero, La Ilíada, VI, 444-446.

31. Adrados, Introducción a Homero, 291. 
Ahora bien, además de virtudes morales y físicas, existen otros temas que rodean la figura del héroe épico. Estudiosos como Lord Raglan, ${ }^{32}$ entre otros, se han dado a la tarea de enumerar los motivos que forman parte de la historia o vida de un héroe, aunque no específicamente del héroe homérico. No obstante, como bien dice A. Brelich, ${ }^{33}$ no es posible realizar un esquema general del mito heroico, y pese a que existen temas míticos recurrentes en la mitología heroica (al igual que en la divina), éstos no siempre suelen manifestarse por igual en cada personaje.

Dentro de los numerosos héroes homéricos, si no el más destacado, el que se volvió el arquetipo de ellos fue Aquiles, procedente de linaje divino y muerto en el campo de batalla durante su juventud. Como apunta Carlos Bermejo, ${ }^{34}$ es un error querer estudiar a cualquier héroe basándonos en este prototipo y generalizar a partir de él al conjunto de héroes épicos, ${ }^{35}$ pero es un hecho que los temas establecidos por su mitología heroica se volvieron prototípicos de la figura del héroe homérico, y me ha parecido posible identificarlos, tras un detallado examen analítico, en los esquemas visuales del Vaso François. A saber: I) origen/linaje divino, 2) iniciación, 3) hazañas heroicas y 4) muerte gloriosa en la juventud.

\section{Origen/linaje divino del héroe: bodas de Tetis y Peleo}

Como ya describí con anterioridad, en este friso se ve un cortejo de dioses que se dirige al oíkos de los recién casados para entregar ofrendas nupciales.

El antecedente de este matrimonio se remonta a cuando Zeus y Posidón pretendían a Tetis, hija de Nero, pero Temis y Prometeo vaticinaron que el hijo de ésta sería más fuerte que su padre, dando a entender que si el padre fuera Zeus, el hijo que naciera reinaría en el cielo. Fue entonces que Zeus, por

32. Lord Raglan, The Hero (Nueva York: Oxford University Press, 1937), 205-230.

33. Angelo Brelich, Gli eroi greci. Un problema storico-religioso (Roma: Ateneo, 1978), 300-31I.

34. Bermejo, Los origenes de la mitología griega, 16-33.

35. Por ejemplo, hay un buen número de héroes homéricos que no murieron en batalla, como Agamenón (asesinado por Clitemnestra en sus aposentos), Menelao (que logró regresar a Micenas despúes de la guerra de Troya y al término de su vida, fue transportado, sin morir, por Zeus a los Campos Elíseos), Áyax (que cometió suicidio) u Odiseo (que después de la guerra de Troya logró regresar, aunque mucho tiempo después, a su hogar junto con su hijo y su esposa). 
DOI: http://dx.doi.org/10.22201/iie.18703062e.2017.1.2591

IOO

miedo a tal profecía, escogió a un mortal para ser el marido de la nereida. ${ }^{36} \mathrm{Si}$ tomamos en cuenta este pasaje, en la boda de Tetis y Peleo se conjugan diversos aspectos del nacimiento u origen del arquetipo del héroe homérico (en este caso Aquiles), a saber: I) el héroe es hijo de una divinidad (Tetis), 2) el padre es un rey (Peleo, rey de Ptía, en Tesalia, y de los mirmidones), 3) el héroe es un semidiós, hijo de mortal y divinidad, y 4) su concepción o nacimiento vienen acompañados de un vaticinio de destronamiento o muerte del padre (para evitar esto, Zeus decide que el padre sea un mortal y no él), así como de circunstancias inusuales (recordemos la manera en que Peleo obliga a Tetis a contraer nupcias o cómo ésta pretende volver inmortal a Aquiles cuando niño). ${ }^{37}$

Así pues, el discurso visual de las bodas expone el casamiento de un héroe con una diosa; unión de la que nacerá el arquetipo de héroe homérico, Aquiles, cuya grandeza es la constatación del ya mencionado vaticinio de que el hijo de Tetis será más fuerte que su padre. Además, aunque no se le representa en la escena de la crátera, la boda de Tetis y Peleo da pie míticamente a un suceso que tendrá repercusiones importantes en la vida de Aquiles: la aparición de la manzana de la discordia entre Hera, Atena y Afrodita, lo que mucho después propiciará el famoso "juicio de Paris", que provocará el rapto de Helena y la posterior guerra de Troya, ${ }^{38}$ donde Aquiles alcanzará su gloria máxima, morir joven en batalla, suceso representado en el friso por el ánfora que carga Dioniso, pues este regalo de bodas para Tetis, que seguramente contenía vino para la celebración, se convirtió en la posterior urna funeraria del héroe. ${ }^{39}$

\section{Iniciación del héroe: Géranos de Teseo y cacería del jabali de Calidón}

\section{Géranos de Teseo}

En el lado "teseida" de la crátera, ubicado en el friso superior del cuello, después de las firmas fragmentadas del alfarero y pintor (Ergótimos m'epoíesen, "Ergótimos me fabricó", y Klitias mégraphsen, "Klitias me pintó"), aparece una escena preiliádica, pero que, por su importancia para el pueblo ateniense, se

36. Apolodoro, Biblioteca, trad. Javier Arce (Madrid: Gredos, 200I), III, I3, 5 .

37. Apolodoro, Biblioteca, III, I3, 5-6.

38. Apolodoro, Biblioteca, Epítome, 3, I-7.

39. Homero, La Odisea, trad. J. M. Pabón (Madrid: Gredos, 1993), XXIV, 73-77; Homero, La Ilíada, XXIII, 9I-92. 
coloca aquí para referirse a la etapa iniciática del héroe homérico. $4^{\circ}$ Observamos la nave de Teseo arribando a una isla. En la nave, varios marinos aparecen sentados, mientras que otros están de pie y se preparan a desembarcar. Uno de ellos eleva sus brazos y mirada al cielo, acaso en señal de alegría. Otro más, que parece no haber resistido el ansia, se lanza a nado hacia la orilla. El héroe ateniense ya se encuentra en tierra y encabeza, tañendo la lira, el coro de siete jóvenes y siete doncellas que, tomados de las manos e intercalados de uno en uno según su género (un hombre seguido de una mujer), bailan un géranos para celebrar el regreso. Frente a Teseo, mirándolo, aparecen Ariadna, que sostiene el ovillo que garantizó la salida del laberinto, y en un tamańo menor, la nodriza de ésta (figs. I y 3 ).

$\mathrm{Al}$ analizar este friso a la luz del mito, puedo decir que alude al episodio en el que Teseo, después de dar muerte al Minotauro y escapar de Creta, arriba a las costas de Delos y realiza una danza para celebrar su victoria. Sin embargo, la aparición de Ariadna en este episodio parece ser un anacronismo mítico, ya que, para cuando Teseo llega a Delos, la joven ya había sido abandonada junto con su nodriza Corcina en Naxos. ${ }^{4 \mathrm{I}}$ Guy Hedreen apunta, muy acertadamente, que tal vez la función de Ariadna en el Vaso François sea evocar el porqué de la victoria que en esos momentos se celebra, opción que yo favorezco, pues la joven aparece sosteniendo el carrizo con el que Teseo logra salir del Laberinto, que más adelante colgará como ofrenda en el templo delio. ${ }^{42}$

40. Teseo, pese a no formar parte de los héroes que participaron en los sucesos de las narraciones homéricas, tenía un valor muy alto a los ojos de las clases altas del Ática, era la proyección de una realidad pasada que se materializa en la formación de la ciudad, pues la cronología mítica ubica a Teseo una generación antes de la guerra de Troya (acontecida $c a$. 1375 o hasta II89 a. C). Apolodoro (Biblioteca, III, IO, 7 y Biblioteca, Epítome, I, 23) y Plutarco (Vida de Teseo, III-IV) refieren que Teseo, a la edad de 50 años, rapta a Helena cuando ésta apenas tiene I2 ańos, antes de que ella se casase con Menelao y fuera llevada a Troya por Paris. "Por su parte, Pausanias (I, $27,7)$ dice que Teseo tenía siete años para el tiempo en que Heracles ya había conseguido la piel del león de Nemea (Las primeras referencias sobre Heracles nos las proporcionan Homero y Hesíodo, y se remontan a los siglos IX-VIII, aunque sus hazañas son anteriores a las ocurridas en las narraciones homéricas. Específicamente en Homero, La Odisea, XI, 6oI-6I4, se le evoca ya como un difunto). En cuanto a las fechas de la guerra de Troya, Eratóstenes da la fecha de II93-II84; el Marmor Parium, I209-I208; Herodoto (II, I45), I250". Apud Adrados, Introducción a Homero, 233. 4I. Plutarco, Vida de Teseo, XIX, XX y XXI.

42. Guy Hedreen, "Bild, Mythos, and Ritual: Choral Dance in Theseu's Cretan Adventure on the Vase François", Hesperia 80, núm. 3 (2011): 91-510. 
DOI: http://dx.doi.org/10.22201/iie.18703062e.2017.1.2591

IO2

Respecto a esta representación plástica, considerada de manera individual, aislada de los demás frisos de la crátera, y no de manera unitaria, como pretendo hacer aquí, han surgido diversas interpretaciones, unas más afortunadas que otras, y las cuales, por cuestiones de extensión, no reproduciré aquí. ${ }^{43}$ Baste decir que Guy Hedreen analiza, con base en la literatura y la arqueología, diversas explicaciones en torno al friso de Teseo en el Vaso François y concluye lo siguiente: primero, en efecto, la hilera mixta de jóvenes tomados de las manos corresponde a una danza, pues es equiparable a representaciones anteriores de otras piezas cerámicas en las que aparecen hombres y mujeres tomados de las manos y guiados por un personaje que porta un instrumento musical. Segundo, si bien la presencia de Ariadna y del ovillo hacen pensar en los sucesos acontecidos en Creta y no en Delos, es un error interpretar el episodio como un pasaje de enamoramiento, pues la música (representada por la lira del héroe) y la danza no son los elementos principales de la representación plástica, y la habilidad musical de Teseo no puede ser el símbolo de su atractivo sexual. Tercero, en esta imagen se mezcla el presente y pasado de la narración mítica de la derrota del Minotauro. El encuentro de Teseo con Ariadna evoca la llegada a Creta, y los marinos emocionados, así como la danza, aluden a la celebración tras el escape del laberinto. Finalmente, Hedreen explica que la danza de victoria, analizada a la luz de la mitología propia de Ariadna, y con base en ciertos testimonios literarios y en imágenes de jarrones protogeométricos tardíos que muestran bailarines utilizando una cuerda, puede ser vista como un rito de paso en el que sus participantes alcanzan una edad casadera. ${ }^{44}$

Ahora bien, lo que me interesa rescatar del trabajo de Hedreen es el carácter iniciático que se le atribuye a la representación, pero, para efectos de los objetivos e hipótesis de esta investigación, enfocado al mundo mítico heroico.

En la antigua Grecia, un aspecto importante de la vida cotidiana eran los procesos iniciáticos y los rituales de paso, es decir, los momentos en que un individuo pasaba de una etapa de vida a otra. De especial significación era

43. Alan Shapiro, Art and Culture under the Tyrants in Athens (Maguncia: P. von Zabern, 1989), I46-I47; A. Shapiro, "Theseus: Aspects of the Hero in Archaic Greece", en New Perspectives in Early Greek Art (Washington: Buitron-Oliver, 199I), I23-I39, especialmente I24-I26; Luca Giuliani, Bild und Mythos: Geschichte der Bilderzählung in der griechischen Kunst (Múnich: Beck, 2003), I55-195, especialmente I55-I57 y 195-196; Charles Dugas, "L'Évolution de la légende de Thésée”, Revue des Études Grecques, t. 56, fasc. 264 y 265 (enero-junio, I943): I-24, http:dx.doi. org/IO.3406/reg.1943.2966.

44. Hedreen, "Bild, Mythos, and Ritual", 49I-510. 
la transición de adolescente a adulto, cuando un joven se convertía en una persona madura, listo para integrarse a la sociedad y capacitado para, en el caso de los varones, participar en la guerra, y, en el de las mujeres, contraer matrimonio. Por ejemplo, en algunos lugares como Esparta y Creta cuando un joven varón alcanzaba la efebía se le separaba de su familia y se le llevaba con otro grupo de muchachos de su edad con los que, fuera de la ciudad y en un ambiente hostil, debía pasar por una serie de pruebas y aprendizajes para demostrar que era apto para integrarse a la sociedad (resistir condiciones precarias en el vestir y en la alimentación, realizar combates rituales, entre otras). Una vez finalizado el periodo de iniciación, el joven debía realizar una hazaña, que por lo general consistía en enfrentarse o cazar a una fiera salvaje, para demostrar que estaba listo para convertirse en hombre maduro y en un ciudadano.

Era tal la importancia de la etapa iniciática (biológica, social, religiosa) en la vida de una persona que este momento de aprendizaje también permeó de diversas maneras el mundo mítico; por ejemplo, algunos héroes pasaron por uno o varios procesos iniciáticos o de educación durante su niñez-adolescencia. Tal es el caso de Aquiles, que, cuando niño, fue entregado al centauro Quirón, típico maestro de héroes, para que lo instruyese en el arte de la guerra y la hípica, en la caza, la medicina y otras aptitudes bélicas. ${ }^{45}$ Posteriormente, este héroe pasa por una segunda iniciación (travestismo ritual), ${ }^{46}$ cuando Tetis, su madre, enterada por un oráculo de que su hijo moriría si participaba en la guerra de Troya, lo envía a ocultarse al palacio de Licomedes en Esciros, donde al joven lo disfrazan como mujer para pasar desapercibido entre las hijas del rey. ${ }^{47}$ Una versión del mito narra que Odiseo, disfrazado de mercader, fue a buscarlo para que los acompańase a Troya, pues la profecía decía que no podrían obtener la victoria sin la participación de Aquiles. Odiseo colocó magníficos regalos ante las hijas de Licomedes, las verdaderas mujeres escogieron telas y utensilios para bordar, mientras que Aquiles, traicionado por su vocación guerrera, tomó algunas armas, con lo que quedó descubierto y admitido en el ejército aqueo.

45. Apolodoro, Biblioteca, III, I3, 6 .

46. Rito iniciático masculino que consiste en la adopción temporal del sexo femenino por medio de ropajes de mujer, dramatizando ritualmente el acceso del joven a la virilidad y al matrimonio (Bermejo, Los origenes de la mitología griega, 262-263).

47. Apolodoro, Biblioteca, III, I3, 8; Homero, La Ilíada, IX, 438-439; XI, 768-782. 
DOI: http://dx.doi.org/10.22201/iie.18703062e.2017.1.2591

IO4

A partir de esta disertación podemos proponer que, en el Vaso François, el friso con el baile de jóvenes encabezado por Teseo efectivamente hace referencia al presente (celebración de victoria) y al pasado (ayudantía de Ariadna) de la narración mítica del héroe Teseo como vencedor del Minotauro. Pero también, y más importante aún, en el contexto del arquetipo heroico aquí propuesto constituye el paso final en el proceso de la toma del poder del héroe. Es la conclusión solemne de una larga serie de pruebas de maduración. Atestiguado esto por el mito, en el cual Teseo, después de rebasar la edad pueril y realizar el respectivo rito de paso que consistió en la oblación de su cabellera alrededor de los 16 años, ${ }^{48}$ en su afán de emular a Heracles y en su camino hacia el reino de Egeo para anunciarse como su hijo, realizó diversas hazañas menores en las que dio muerte a diferentes monstruos y personajes, una vez reconocido por su padre, se dio incluso a la tarea de eliminar al toro de Maratón. ${ }^{49}$ Sin embargo, el hecho más representativo de su maduración es su posterior victoria sobre el Minotauro, tras la cual sucede a su padre, el rey Egeo, en el trono.

\section{Cacería del jabali de Calidón}

Del lado contrario, en el friso superior del cuello del vaso, podemos ver la cacería del jabalí calidonio (figs. 2 y 4), escena enmarcada a ambos lados por una esfinge rampante. La fiera, con el cuerpo cubierto de flechas, es el centro de la representación, a diestra y siniestra la emboscan cazadores jóvenes que sostienen lanzas o tensan sus arcos; entre ellos se encuentra una mujer, la famosa heroína Atalanta, reconocida tanto por su inscripción nominal, como por el color blanco de su piel, propio de representaciones femeninas. En la escena no pueden faltar varios perros de caza, de los cuales uno ha encontrado la muerte al enfrentarse a la bestia y yace de espaldas frente a un cazador tendido en el suelo, seguramente muerto. La situación corresponde bastante bien a la descrita por algunos mitógrafos griegos. ${ }^{50}$

Según lo ilustran las abundantes escenas de cacería en los mitos griegos, un héroe no sólo debe iniciarse y destacar en la guerra y en el deporte, como veremos más adelante, sino también en la caza (realizada fuera de la ciudad, del mundo civilizado, donde se inicia a los efebos), que contribuye a su entrena-

48. Plutarco, Vida de Teseo, V; Pierre Vidal-Naquet, Formas de pensamiento y formas de sociedad en el mundo griego, trad. Marco Aurelio Galmarini (Barcelona: Península, 1983), I39.

49. Plutarco, Vida de Teseo, VIII-IX, XIV; Apolodoro, Biblioteca, II, 6, 3; III, I6, I ss.; Epítome, I, I ss.

50. Apolodoro, Biblioteca, I, 8, 2. 
miento bélico, pues para realizarla se necesita tener inteligencia superior a la del animal salvaje y sobreponer la astucia a la fuerza bruta..$^{5 \mathrm{I}}$ Pero no estamos hablando de cualquier tipo de caza, mucho menos de la cacería salvaje, solitaria, donde se usan ardides y redes y que es propia de "jovencitos", de adolescentes, sino de aquella que va de acuerdo con la condición del adulto, en la que se usan perros entrenados y venablos y se realiza de manera colectiva, ${ }^{52}$ en donde sobresale del grupo aquel que efectúe el golpe maestro y provoque la muerte al animal. ${ }^{53}$ Así, en Píndaro escuchamos de Aquiles que mata ciervos "sin perros ni redes tramposas por ser más veloz que ellos". ${ }^{44}$

En este orden de ideas, el discurso visual de la cacería del jabalí calidonio es el prototipo de la caza colectiva (más segura), que representa la preparación de jovencitos para la guerra, y marca su maduración, su paso de cazadores adolescentes a cazadores y héroes maduros. Esto se puede constatar plásticamente porque, en este friso se encuentra Peleo como un joven imberbe (hombre en segundo plano frente al jabalí), que después aparecerá como personaje principal, ya barbado, en el ya estudiado friso nupcial, lo que revela su posterior conversión en héroe-guerrero.

\section{Hazañas bélicas y atléticas: batalla entre lapitas y centauros, friso animal, Geranomaquia y Juegos fúnebres en honor a Patroclo}

La batalla es el ámbito en el que un héroe puede mostrar y probar sus valores morales y guerreros, y obtener con ello, de acuerdo con el objetivo primario del comportamiento heroico, la tan preciada gloria o fama (kléos), lo cual es precisamente el tema de los cantos épicos. Tal es, en efecto, la situación planteada en el conocido pasaje en que la embajada enviada por Agamenón para aplacar la cólera de Aquiles lo encuentra tañendo la fórminx en su tienda y cantando "hazañas de héroes". Es preciso que el honor obtenido en la guerra por un héroe sea pregonado por los demás y, una vez ganado, debe conservar-

5I. Vidal-Naquet, Formas de pensamiento y formas de sociedad en el mundo griego, 152.

52. Véase, por ejemplo, la escena de caza de jabalí en Homero, La Odisea, XIX, 428-454.

53. Vidal-Naquet, Formas de pensamiento y formas de sociedad en el mundo griego, I52-I57; Susana Reboreda, "La iniciación, la caza y el arco en la Grecia arcaica", Minius IV (1995): 56.

54. "Cabe destacar que la utilización de redes no aparece en la tradición plástica relativa al jabalí de Calidón, ni [tampoco] en la tradición literaria." Véase Vidal-Naquet, Formas de pensamiento y formas de sociedad en el mundo griego, I53. 
DOI: http://dx.doi.org/10.22201/iie.18703062e.2017.1.2591

I06

MARYSOL ALHIM RODRÍGUEZ MALDONADO

se. Entonces se dice que la fama del guerrero llega hasta el cielo. Nada desea más el héroe homérico que el reconocimiento, presente y futuro, de su fama. Incluso, ellos mismos pregonan sus excelencias, y no hay modo más directo para excitar su valor que apelar a la fama o al peligro de la mala fama o la censura que le espera al cobarde. 55

\section{Batalla ente lapitas y centauros}

Como ejemplo de una acción de combate heroico, el friso inferior que decora el cuello de esta pieza cerámica, en el lado "teseida", muestra la célebre lucha entre lapitas y centauros en respuesta al conocido "atentado" perpetrado en las bodas de Piritoo e Hipodamía. ${ }^{56}$ Los primeros se defienden a punta de lanza y portan yelmo, escudo y coraza; los segundos, haciendo honor a su naturaleza salvaje y brutal, 57 atacan blandiendo ramas y lanzando piedras contra los guerreros, entre los que se encuentra Teseo, como un indicio más del origen ático de la pieza y de la importancia del héroe para la región, según lo que ya he expuesto arriba (figs. I y 3 ).

Este discurso pictórico es de suma importancia, porque marca el momento en que un héroe se enfrenta a la otredad, a su alteridad; ${ }^{8}$ se "mide" con lo no civilizado; se distingue de lo ágrios (lo salvaje), encarnado por los centauros, a quienes de manera contrastiva se presenta como un antimodelo cultural del héroe homérico, al estar caracterizados por el primitivismo de su actuar y de sus costumbres. Puesto que lo "otro" (to héteron), en este caso el centauro, aparece como componente inseparable del "mismo", como condición de la propia identidad, y como no se puede concebir ni definir el "mismo" sino en relación con el "otro", 59 el simbolismo de la lucha entre lapitas y centauros del Vaso François expone, además de la importancia guerrera en el arquetipo homérico, la manera en que el héroe reafirma su naturaleza como hombre civilizado.

55. Homero, La Ilíada, VII, 87-9I; VIII, 229; IX, I85-189; XI, 390; XII, 39I; XV, 348, 657; XX, 362; Homero, La Odisea, IX, 20; XXI, 323.

56. Apolodoro, Biblioteca, Epítome, 21; Plutarco, Vida de Teseo, XXX.

57. Geoffrey Stephen Kirk, El mito. Su significado y función en la antigüedad y en otras culturas, trad. Teófilo de Loyola (Barcelona: Labor, 2005), 20-25.

58. Alcira Beatriz Bonilla, "La Medusa y el extranjero de Elea", en VIII Jornada sobre el imaginario en el mito clásico (Buenos Aires: CEI, 2007), 2.

59. Jean-Pierre Vernant, La muerte en los ojos. Figuras del "otro" en la antigua Grecia, trad. Daniel Zadunaisky (Barcelona: Gedisa, 1996), 37-38. 


\section{Friso animal}

En la Ilíada es común encontrar comparaciones entre los leones atacando a su presa y los héroes luchando contra sus enemigos, lo que refleja el ánimo valeroso y combatiente del guerrero en batalla: "Como un león agrede a los rebaños que carecen de guarda/de cabras o de ovejas y se arroja feroz contra ellas,/así el hijo de Tideo acometió a los guerreros tracios,/hasta matar a doce" ${ }^{60}$

Este recurso literario homérico es retomado y vertido de manera gráfica por Klitias en el Vaso François para, muy probablemente, dar una idea de la ferocidad del héroe en la guerra (figs. I-5).

\section{Geranomaquia (lucha de pigmeos contra grullas)}

En el pie del vaso aparece el enfrentamiento que sostuvieron los pigmeos, un pueblo de enanos egipcios, contra las grullas o cigüeńas. Por lo general, esta escena, en el arte griego antiguo y egiptizante, tiene un matiz cómico, los pigmeos son representados como enanos desproporcionados, a veces con rasgos negroides, con vientres prominentes y con muslos pingües, como en un aríbalo de figuras negras de Nearco, ática, 575-525 a. C. ; ${ }^{61}$ sin embargo, en la crátera o Vaso François, sus cuerpos guardan las debidas proporciones de un hombre común, sólo que en menor escala, lo que deja de lado la comicidad tradicional atribuida a estos personajes (fig. I-5).

Propongo entonces interpretar esta escena, primero como una referencia, de manera indirecta, a la lucha guerrera contra lo salvaje (lo ágrios, como se vio en el friso con centauros y lapitas), encarnado por las grullas y, segundo, como una alusión al estrépito de la batalla, pues con frecuencia los griegos asemejaban el graznido y el vuelo de la grulla con el ruido y el desorden producido en la guerra:

Los troyanos marchaban con vocerío y estrépito igual que pájaros,/tal como se alza delante del cielo el chillido de las grullas,/que, cuando huyen del invierno y del indecible aguacero,/entre graznidos vuelan hacia las corrientes del océano,/llevando a los pigmeos la muerte, y a través del aire les tienden maligna disputa. ${ }^{62}$

6o. Homero, La Ilíada, X, 485-488.

6I. Museo Metropolitano, Nueva York; cVA \# 300770.

62. Homero, La Iliada, III, 2-7; también II, 460 ss. 
DOI: http://dx.doi.org/10.22201/iie.18703062e.2017.1.2591

IO8

MARYSOL ALHIM RODRÍGUEZ MALDONADO

\section{Juegos fúnebres en honor a Patroclo}

Ahora bien, los héroes homéricos no sólo debían sobresalir en el campo de batalla y en el ejercicio de la caza, como lo hemos visto, sino también en agones atléticos ${ }^{63}$ un ámbito en que se tendía a heroizar a los ganadores, como lo demuestra la práctica de la composición de epinicios en su honor por parte de grandes poetas como Píndaro, Baquílides y Simónides. De hecho, tenemos evidencias literarias de que los guerreros gustaban de participar en tales competencias. Entre las diversas ocasiones que había para celebrar torneos atléticos, cuya abundancia es tan grande que no podemos abordarla aquí, se encuentran los juegos que se realizaban tras la muerte e incineración de un héroe. Y ésta era ocasión no sólo para honrar al difunto, sino también para que sus compañeros sumaran a sus hazañas bélicas las atléticas, que también les servían de entrenamiento para el combate y les daban la reputación de áristoi ("nobles") - héroes-atletas invencibles. ${ }^{64}$

Así pues, en el segundo friso que decora el cuello del lado "calidonio" de la crátera o Vaso François, Klitias plasmó los juegos fúnebres en honor a Patroclo, apoyado claramente en el episodio correspondiente de La Ilíada: cinco cuadrigas, de las cuales una, la que va a la cabeza de la carrera, está fragmentada, se dirigen a la "meta", simbolizada por la figura de Aquiles, que los espera de frente, para otorgar como premio al vencedor los trípodes y calderos plenamente identificables en la escena (figs. 2 y 4 ). ${ }^{65}$

Al recordar con Jean-Pierre Vernant que "el combate aristocrático de la época arcaica era una prueba de valor individual" diferente al posterior combate hoplítico que "había introducido el trabajo en equipo y la cooperación como elementos decisivos", y que el objetivo de las competiciones era "vencer individualmente a los adversarios y compartir la gloria de la victoria con la propia familia y la ciudad", ${ }^{66}$ se puede pensar que el discurso visual presentado en estos frisos de la crátera o Vaso François expresa el desenvolvimiento de sus protagonistas ya totalmente iniciados, aceptados y realizados dentro del ámbito heroico. Se trata también de la expresión de su superioridad "individual", no sólo en el campo de batalla, entendido como la guerra o

63. Hugo Bauzá, El mito del héroe griego (México: Fondo de Cultura Económica, 1998), 3I.

64. Homero, La Iliada, XXIII, I3 y 253.

65. Homero, La Ilíada, XXIII, 258-633, 634-739, 740-792, 826-849, 850-883, 884-897.

66. Jean-Pierre Vernant, El hombre griego, trads. Pedro Bádenas y Antonio García (Madrid: Alianza Editorial, I993), II9. 
la competencia deportiva, sino también su superioridad frente al mundo de la otredad salvaje, expresada, como ya expliqué arriba, en la victoria sobre los salvajes centauros, además de representar una prueba de fuerza respecto al mundo de la igualdad aristocrática, pues hay que recordar que era sumamente importante para un héroe "medirse", probarse y vencer, también en relación con sus iguales, con sus semejantes (isoi, homoioi), lo que queda reflejado en los agones fúnebres de Patroclo. ${ }^{67}$

Muerte gloriosa en la juventud e inmortalidad: la muerte de Troilo y el sitio de Troya, Ayax cargando el cuerpo de Aquiles, Gorgo y Ártemis

La muerte heroica es un premio para el guerrero homérico, quien debe morir joven, en batalla, pues sólo así logrará la gloria máxima, la inmortalidad, pero no una inmortalidad física, como la que obtiene Heracles (que, como ya mencioné, no es personaje homérico) en su apoteosis y acceso al Olimpo después de su extinción como mortal, sino una permanencia en la mente de su pueblo, que recordará y cantará por siempre su fama y hazañas. ${ }^{68}$

\section{La muerte de Troilo y el sitio de Troya}

Cuenta la tradición que existía un oráculo según el cual Troya no podría ser derrotada si, Troilo, el hijo menor de Príamo y Hécuba, llegaba a la edad de 20 años, por lo que Aquiles lo asesinó. Algunos autores refieren que, cuando Aquiles lo vio acarreando agua de una fuente, lo persiguió hasta el templo de Apolo, donde lo traspasó con una lanza. ${ }^{69}$

67. Homero, La Ilíada, XXIII; Adrados, Introducción a Homero, 449-460.

68. Homero, La Ilíada, VII, 87-90; XII, 322-325; Homero, Odisea, V, 306 ss.; Bauzá, El mito del héroe griego, 3I, 17I-172; Francisco Flores Arroyuelo, "Del héroe de la antigüedad al personaje literario", Memorias de la Real Academia de Buenas Letras de Barcelona, 25 (2000), 232-233; Adrados, Introducción a Homero, 293. Aunque Teseo, protagonista del friso inicial, no muere joven ni en batalla. Plutarco dice que cuando el héroe raptó a Helena, éste tenía 50 años (Plutarco, Vida de Teseo, XXXI) y, junto con Pausanias, refiere que Licomedes lo asesinó empujándolo de un risco, aunque también, según la misma fuente, existe la posibilidad de que el héroe haya resbalado cuando paseaba ebrio después de comer (Plutarco, Vida de Teseo, XXXV).

69. Apolodoro, Biblioteca, III, I2, 5; Epítome, 3, 3I-32; Homero, La Ilíada, XXIV, 257. 
En el vientre del lado "calidonio" se encuentra el discurso visual con el sitio de Troya: varios dioses y guerreros, tanto del bando aqueo como del troyano, aparecen en escena. Llama la atención la presencia de una fuente (elemento importante en este mito, como se verá a continuación), representada por la naos de un templo con mascarones leoninos por donde brota el agua, e identificada con la inscripción kréne. Al centro de la imagen, de manera fragmentaria, Aquiles persigue a Troilo. Éste, montado a caballo, se dirige hacia los muros de Troya. Allí, su padre, el rey Príamo, lo espera en actitud sedente. A los pies del caballo del joven, se aprecia una hidria volcada, con la que probablemente recogía agua y que dejó caer tras la presurosa huida. También puede verse a Héctor atravesando las puertas de la ciudad para participar en la batalla (figs. 2 y 4).

Éste es un tema íntimamente ligado a la muerte del héroe homérico, no tanto por la temática de la escena, la muerte de Troilo, ${ }^{70}$ una figura menor, sino porque este hecho forma parte de los detonadores de la más famosa muerte homérica que se haya predestinado, la de Aquiles, pues "Posidón y Apolo se comprometieron a vengar la muerte de Cicno y de Troilo y a castigar ciertas jactancias insolentes que Aquiles había pronunciado sobre el cadáver de Héctor" $7^{71}$

\section{Ayax cargando el cuerpo de Aquiles}

El friso con la representación del sitio de Troya y su implicación mítica posterior remite inmediatamente o da pie al discurso visual de los paneles ubicados en las asas de la crátera, en las cuales, decoradas en las laterales con una línea de palmetas, se aprecian tres registros decorativos: en el primero, en la cara interior de la voluta, aparece Gorgo (fig. 7); el registro central presenta la figura de la diosa Ártemis personificada como Pótnia Therón, y el panel inferior muestra la imagen de Áyax barbado cargando el cadáver imberbe, desnudo y desarmado de Aquiles (figs. 5 y 6). Esta última escena representa justamente la "bella

70. En el siglo vi la muerte de Troilo era uno de los temas favoritos de los ceramistas por representar un contenido afín al espíritu de la época: el ciclo de la hybris (rebelión contra el orden natural del mundo basado en la supremacía de los dioses), en el cual Aquiles mata a Troilo y recibe un castigo igualitario, su propia muerte. Karl Schefold, "Poésie homérique et art archaïque", Revue Archéologique. Nouvelle Serie I: Études de céramique et de peinture antiques offertes à Pierre Devanbez, núm. I (1972): 9-22.

7I. Robert Graves, Los mitos griegos II (Buenos Aires: Losada, 200I), 428; Apolodoro, Biblioteca, Epítome, 3. 
muerte" del héroe. Aquiles, a sabiendas del destino que le espera, se lanza a la batalla, pues prefiere perecer tempranamente a tener una larga vida sin gloria. ${ }^{72}$

La ausencia de barba indica la corta edad del héroe. Por otra parte, esta representación plástica discrepa en el aspecto iconográfico de las fuentes literarias en cuanto a la desnudez del héroe, pues en ellas, cuando Áyax rescata el cuerpo de Aquiles, éste aún no había sido despojado de sus armas. ${ }^{73} \mathrm{Al}$ respecto, L'Homme-Wéry plantea que, pese a que Aquiles está identificado por su correspondiente inscripción, el hecho de que esté desnudo le da cierto anonimato que permite convertirlo en la representación genérica, en el arquetipo de todos los héroes de la épica griega antigua; por tanto, esta escena sería la representación genérica, arquetípica, de la "bella muerte" del héroe homérico. ${ }^{74}$

\section{Ártemis como Pótnia Therón}

Ahora bien, ¿qué relación tienen con la "muerte" del héroe homérico las otras dos figuras que decoran las asas: Ártemis como Pótnia y Gorgo? (figs. 5-7). Por un lado, Ártemis, caracterizada como Pótnia Therón, carente de inscripción pero identificada por su figura alada y la típica posición en la que sostiene en una mano una pantera y en la otra un ciervo (o una pantera en cada mano), es la diosa de las fieras y lo salvaje.

Respecto a esta imagen, la L. M. L’Homme-Wéry, con base en representaciones semejantes hechas por el pintor de Amasis en las que Pótnia aparece en contexto guerrero o atlético, rodeada de jóvenes luchando o practicando algún ejercicio, apunta que la diosa Ártemis en el Vaso François, por estar colocada en el mismo espacio que la imagen de Áyax cargando el cuerpo de Aquiles, representa a la diosa madre protectora de los guerreros. Ella asegura que cuando un guerrero muere, su cuerpo no será devorado por las bestias o ultrajado por el enemigo, sino recuperado por sus compañeros, como lo hace Áyax con Aquiles, para otorgarle un funeral adecuado. ${ }^{75}$

Por mi parte, no apoyo tanto este simbolismo en la crátera o Vaso François, pues, si bien Áyax recupera el cuerpo de Aquiles, se presenta desnudo, lo cual

72. Homero, La Ilíada, IX, 4IO-4I6; Apolodoro, Biblioteca, Epítome, 5, 3-4.

73. Homero, La Odisea, XI, 543-549.

74. L'Homme-Wéry, "L'Athènes de Solon sur le Vase François", 279.

75. L'Homme-Wéry, "L'Athènes de Solon sur le Vase François", 284. 
DOI: http://dx.doi.org/10.22201/iie.18703062e.2017.1.2591

II2 MARYSOL ALHIM RODRÍGUEZ MALDONADO

indica que los enemigos ya lo han despojado de sus armas. Me inclino más por atribuirle a Ártemis un carácter como diosa de los ciclos de la vida y la muerte, de las transiciones y de los límites, aquí preside el momento de franquear, de pasar de una etapa de vida a otra, a la muerte. ${ }^{76}$

\section{Gorgo}

En el vaso, como en muchas otras piezas cerámicas o arquitectónicas, a Gorgo (fig. 7) se le representa alada, en la posición de la típica carrera arrodillada (rostro y torso de frente, y brazos y piernas de perfil), mostrando la lengua en una mueca feroz, y con serpientes por cabello.

L. M. L’Homme-Wéry afirma que Gorgo cumple con una función apotropaica (que aleja el mal o propicia el bien), propia de la mueca con la que se le representa, y que junto con la Pótnia protege al guerrero contra la muerte para que pueda a su vez velar por la ciudad, representada, en el caso de la crátera en cuestión, debajo de una de las asas por el Hefesto (representante del artesanado) colocado al final de la procesión del friso de las bodas de Tetis y Peleo (fig. 5a) (mas no así en la otra asa, cuya parte inferior enmarca a las musas Polimnia, Erato y Terpsícore, fig. 5 b). ${ }^{77}$

También en este caso he optado por contradecir un poco la idea de protección, y ver a Gorgo, más que como protectora, como un símbolo de muerte. En La Ilíada se la asocia con el espanto del campo de batalla y con la furia bélica que posee el guerrero y que se manifiesta en su apostura, en la cabellera larga y deslumbrante, en su mirada terrible, en el rictus amenazador, en el aspecto salvaje y en los gritos y rechinar de los dientes (odónton kanaché); en La Odisea es un "horrendo monstruo". ${ }^{8}$

Según Vernant, "desde su morada en el fondo del Hades, la cabeza de guardiana de Gorgo vigila las fronteras del reino de Perséfone. Su máscara expresa la alteridad extrema del mundo de los muertos, al que ningún vivo se puede acercar" ${ }^{79} \mathrm{El}$ rostro de Gorgo vuelve el rostro del vivo, en este caso del guerrero homérico, en el rostro de un muerto.

Entonces, el simbolismo de Gorgo y Ártemis en la iconografía y progra-

76. Vernant, La muerte en los ojos, 3I; 1987, I35.

77. L'Homme-Wéry, "L'Athènes de Solon sur le Vase François", 286.

78. Homero, La Ilíada V, 74I; VIII, 349; XI, 36; XI, 633-635.

79. Vernant, La muerte en los ojos, 63-64. 
ma compositivo de la crátera alude directamente a la última etapa del ciclo de vida de un héroe homérico: la muerte, que es terrible y bella al mismo tiempo; terrible porque sucede en la encarnizada batalla y en plena juventud, y bella porque, como ya mencioné, brinda la gloria máxima al héroe.

\section{El regreso de Hefesto al Olimpo, un friso de difícil interpretación}

En el lado teseida encontramos una representación que parece incompatible con el paradigma o hilo conductor de la pintura que he venido reconstruyendo: el ciclo de vida de un héroe homérico. Se aprecia cómo Hefesto, ebrio, montado en un burro y acompañado por Dioniso y su thiasos, es decir, varias ninfas y silenos itifálicos (uno carga un odre con vino, toca el díaulos, y un tercero carga, acaso a la fuerza, a una ninfa), regresa al Olimpo después de haber sido arrojado, expulsado de allí por su cojera. ${ }^{80}$ Los principales olímpicos, entre los que se encuentran Zeus y Hera sentados en sus tronos, completan el cuadro. Afrodita, quien ha sido prometida en matrimonio al dios herrero, es quien lo recibe (figs. I y 3 ).

¿Por qué Klitias habrá retratado aquí a Hefesto si no tiene relación directa con alguna figura heroica de importancia, y, más aún, si dentro de los olímpicos es una divinidad menor? Si bien es cierto que este friso pareciera romper con el discurso unitario del vaso propuesto, se puede decir que el pintor lo aprovechó o colocó ahí con plena conciencia, ya que el mito del regreso de Hefesto al Olimpo estaba sumamente difundido en la época de elaboración de la crátera de estudio, como confirma su presencia abundante en gran cantidad de piezas de cerámica manufacturadas en el siglo vi a. C. en Atenas, pues representaba la dignificación e impulso al artesanado ocurridos gracias a los cambios sociales realizados por el legislador Solón. ${ }^{81}$

Otro suceso significativo para el artesanado durante la tiranía pisistrátida es la inauguración del ágora (zona tradicionalmente dedicada al trabajo artesanal desde la Edad de Hierro) como centro cívico de la ciudad, y la posterior inclusión en ella de Hefesto, el dios de los artesanos (en el distrito de Kolonos Agoraios, cerca del Cerámico), pero ¿puede de alguna manera asociar-

8o. Homero, La Ilíada, I, 586-594; XVIII, 394-409; Apolodoro, Biblioteca, I, 3, 5; II, 7, I.

8I. José María Blázquez Martínez, "La situación de los artistas y artesanos en Grecia y Roma”, Artistas y artesanos en la antigüedad clásica. Cuadernos Emeritenses, núm. 8 (1994): 9-28. 
DOI: http://dx.doi.org/10.22201/iie.18703062e.2017.1.2591

II4

se tal representación figurada en este caso específico a la propuesta relativa al arquetipo o al mundo heroico homérico? Tratemos entonces de responder a esta interrogante.

Dos son los protagonistas de esta representación: Hefesto, que vuelve al Olimpo, y Dioniso, el responsable del regreso. A simple vista, la escena representa la reincorporación de Hefesto al panteón olímpico, pero, atendiendo a la tradición literaria, también expresa la aceptación-incorporación de Dioniso entre los dioses, pues recordemos que, fruto de los amores prohibidos de Zeus y Sémele, a Dioniso lo enviaron lejos de Grecia, a Asia, donde pasó su niñez escondido por las ninfas Híades para protegerlo de Hera, la legítima esposa de Zeus. Al llegar a la adultez, Hera lo descubrió, lo enloqueció y lo obligó a vagar por Egipto y Siria. Finalmente, al llegar a Siria, la diosa Cibeles, o Rea, según otras versiones, lo liberó de la locura, pero el dios aún continuó errante. Se trasladó a Tracia, donde el rey Licurgo trató de hacerlo su prisionero. Dioniso escapó ocultándose en el fondo del mar; una vez a salvo, continúo su viaje hacia la India, luego a Tebas, en Beocia, lugar natal de su madre, y donde instauró las Bacanales, luego a Argos y finalmente a Naxos, en cuyo camino unos piratas trataron de venderlo como esclavo. ${ }^{82}$

En este breve resumen es evidente que Dioniso prácticamente era un dios sin patria, perseguido, y cuya divinidad no había sido del todo aceptada por dioses ni hombres. Desde el punto de vista histórico, y a pesar de que una de las tablillas del palacio de Néstor en Pilos muestra que tenía categoría de dios ya en el siglo XIII a. C., en realidad por mucho tiempo se le consideró un semidios, hasta que, a finales del siglo viI, Periandro, tirano de Corinto, Clístenes, tirano de Sición, y Pisísrato, tirano de Atenas, decidieron aprobar su culto e instituir los festivales dionisiacos oficiales. ${ }^{83}$

Esta aceptación histórico-social del culto a Dioniso en Atenas, al igual que la del culto a Hefesto, como ya vimos, puede justificar su aparición en el Vaso François (donde Dioniso aparece con su thiaos, común en representaciones del regreso de Hefesto, pero no en imágenes donde Dioniso aparece solo, lo que alude a una procesión ritual relativa a su culto y da fuerza a la presencia de este dios), ${ }^{84}$ pero se aleja de la interpretación heroica aquí propuesta. Tratemos de verlo entonces a la luz del mito y de la plástica.

82. Apolodoro, Biblioteca, III, 4-5; Homero, La Ilíada, VI, I3O-I4O;

83. Graves, Los mitos griegos I, I4I.

84. Guy Hedreen, "The Return of Hephistos, Dionysiac Processional Ritual and the Creation of a Visual Narrative", The Journal of Hellenic Studies, núm. I24 (2004), 43. 
Si bien el mito narra que tras la derrota de los piratas en Naxos el poder de Dioniso fue reconocido y pudo ascender al cielo, iconográficamente esta integración como divinidad puede verse claramente en las representaciones creadas a partir del 580 en las que él y Hefesto llegan juntos al Olimpo, como sucede en el Vaso François. Así, la aceptación en el Olimpo de ambas divinidades, tanto en la literatura como en las artes, establece el balance del poder entre los dioses, que ahora se encuentran completos. ${ }^{85}$

Entonces, ¿qué importancia tienen los olímpicos en el vaso y de qué manera se vinculan con el arquetipo del héroe homérico plasmado en la pieza? La epopeya griega tiene como tema principal las gestas de héroes, pero también de dioses, como se lee en La Odisea, I, 338, pues éstos son imprescindibles en el curso de las acciones humanas, ya que su naturaleza divina, sobrehumana, inmortal (que los vuelve más bellos, fuertes e inteligentes que los hombres) es la antípoda de la naturaleza humana, frágil, mortal. ${ }^{86}$

A grandes rasgos, los dioses son quienes proporcionan a los héroes, a esos hombres superiores, sus cualidades especiales, ya sea belleza, fuerza, valor, osadía o astucia, y quienes protegen a algunos de ellos en el campo de batalla. Además, son los encargados de los sucesos que interumpen el orden del cosmos, así como del éxito o fracaso de las empresas humanas. ${ }^{87}$ Como los talentos humanos y los eventos de la existencia de los hombres están sometidos a la influencia de los dioses (por ejemplo, son ellos quienes deciden la guerra y caída de Troya), su presencia se vuelve indispensable en la épica homérica y, por tanto, en la vida de sus héroes ${ }^{88}$ argumento por el que es válido suponer que en el Vaso François se les reservó un lugar en uno de los frisos inferiores, como si sostuvieran todo el universo mítico-heroico de la pieza en cuestión.

\section{Conclusiones}

Para corroborar que los esquemas visuales del Vaso François corresponden a un esquema cultural procedente de la épica griega, a saber, el arquetipo del héroe

85. Hedreen, "The Return of Hephistos, Dionysiac Processional Ritual and the Creation of a Visual Narrative", 38-64.

86. Homero, La Ilíada, V, 44I-442, VI, I42-I46.

87. Homero, La Odisea, VIII, I67 ss.; Homero, La Ilíada, III, 54, VII, 288, XVII, IOI, XV, 467 , IX, 600, XI, 792, XV, 403.

88. Adrados, Introducción a Homero, 276. 
DOI: http://dx.doi.org/10.22201/iie.18703062e.2017.1.2591

II6

homérico, no sólo fue de vital importancia para relacionar esquemas pictóricos y culturales, sino también para atender a ciertas marcas o indicios interpretativos conferidos por elementos formales e inscripcionales de la cerámica. El primero de ellos es la forma misma de la pieza, más grande y redonda que lo convencional, al menos para el tipo cerámico que le corresponde, sobre todo en lo que respecta al diámetro de los hombros.

El segundo indicio es la mayor anchura y prolongación a ambos lados de la pieza de uno de los frisos superpuestos (las bodas de Tetis y Peleo), justamente ubicado en los hombros. Tanto la redondez del vaso, como dicha prolongación del friso nupcial, sugieren un carácter de totalidad, de unidad, primero entre ambos lados del vaso y, segundo, entre sus múltiples frisos; indica también que éstos deben analizarse como un todo, regidos por un hilo conductor (en este caso el arquetipo del héroe homérico), y no como temáticas o escenas aisladas.

La tercera marca interpretativa corresponde a las firmas del alfarero y pintor, repetidas en cada lado de la pieza, lo que no era para nada común. La primera vez en el friso de mayor anchura (friso de bodas), a la altura de los hombros; la segunda, en el lado contrario, en el friso superior del cuello (géranos de Teseo). La repetición y posición de estas grafías confieren importancia extra a los frisos en los que se encuentran y, si se suma a ello la mayor anchura del friso nupcial, su prolongación a ambos lados de la cerámica y su posición en la parte más prominente y redonda del vaso, los hombros, resulta sumamente válido considerarlo como el punto de partida para comenzar el análisis, seguido del estudio del friso del géranos, segundo en importancia por la presencia de las firmas de sus creadores y por el peso mítico-social que su protagonista, Teseo, héroe nacional de Atenas, tiene para los habitantes de esa ciudad.

A partir de aquí se analizaron de manera confrontada uno a uno los frisos de cada lado, denominados éstos para fines de este trabajo como "lado calidonio" y "lado teseida", atendiendo al primer motivo mítico de cada lado (pues los temas de ambos no pertenecen a un mismo ciclo o a un mismo personaje) y con la finalidad de romper el esquema tradicional de lado "A" y "B", que sugiere una separación más tajante y le resta sentido de unidad a la pieza. Se vincularon también ciertas escenas del cuerpo con las representaciones del pie o de las asas, según fuera el caso, método que refuerza la teoría de totalidad sugerida para el vaso.

Ahora bien, varias de las narraciones épicas del Vaso François son preiliádicas, es decir, pertenecientes a tiempos anteriores a los acontecimientos referidos en las narraciones homéricas; algunas están relacionadas con Peleo, padre de Aquiles (bodas de Tetis y Peleo, caza del jabalí Calidón); otras, con Teseo (géranos 
en Delos, lucha entre lapitas y centauros), héroe ateniense; otras más pertenecen propiamente al ciclo iliádico, relacionadas específicamente con Aquiles, el arquetipo por excelencia del héroe homérico (sitio de Troya y muerte de Troilo, juegos fúnebres en honor de Patroclo, Áyax cargando el cuerpo de Aquiles, e incluso las bodas de Peleo y Tetis, matrimonio del que nacerá dicho héroe). Y pese a que no todos los mitos y personajes representados en la pieza son parte de las narraciones homéricas o cronológicamente no están ubicados en la época en la que se desarrollan los sucesos recogidos en ellas (como el mito de la derrota del Minotauro, acontecida mucho antes de la guerra de Troya [ $c$ a. 1375 o hasta II89 a. C.], acaso alrededor de 1420 a. C. o antes), al ser importantes o representativos para la cultura del siglo vi e inicios del v a. C. o para la tradición mítica griega en general (como el caso de Teseo, héroe por antonomasia del Ática con importantes repercusiones sociopolíticas en Atenas, lugar de procedencia del vaso), son utilizados por el pintor del vaso como pretexto para representar y transmitir una tradición mítico-cultural de gran envergadura: la concepción del héroe homérico. Esta figura se gesta desde la época micénica y se transmite por las narraciones homéricas, y su importancia se enfatiza durante la tiranía pisistrátida, momento en que se regula de manera oficial la recitación de La Ilíada y La Odisea, y las hazañas homéricas se vuelven muy familiares y añoradas por los atenienses de la época.

Si bien la figura heroica homérica, diferente de la figura heroica trágica, no puede ni debe generalizarse, pues cada héroe presenta sus particularidades, discrepancias y ciclos propios, el pensamiento heleno definió un arquetipo basado en uno de sus máximos exponentes: Aquiles. Tal modelo expresa que el héroe homérico, además de ser un semidiós y aristócrata, debe, después de su respectiva etapa de maduración, ser un destacado guerrero-atleta cuyo destino y gloria máxima serán cumplidos únicamente con una muerte temprana, en plena flor de la juventud.

Tras mi investigación y análisis puedo aseverar que dicho modelo o concepción está inteligentemente plasmado en el Vaso François de la siguiente manera:

I) La naturaleza o procedencia divino-aristocrática se alude con el friso de las bodas de Tetis y Peleo, discurso visual que versa sobre el casamiento de un rey con una diosa marina, unión de la que nacerá el mismísimo Aquiles.

2) El paso de la efebía a la edad adulta, a la madurez, es un momento iniciático, de aprendizaje, en el cual al héroe homérico se le reconoce como tal por haber adquirido las herramientas necesarias para desenvolverse adecuadamente en la sociedad, en el campo de batalla y en el ámbito de la caza. En el 
DOI: http://dx.doi.org/10.22201/iie.18703062e.2017.1.2591

II8

Vaso François esta transición se ejemplifica en las escenas del géranos teseida y de la cacería calidonia, ambas plasmadas en la mitad superior del cuello de la vasija, en lados opuestos. La primera narración plástica, en la que un grupo de jovencitos baila junto con Teseo para celebrar su victoria en el laberinto cretense, expresa claramente cómo el héroe nacional de Atenas cumplió con el "requisito" iniciático de enfrentarse a diferentes peligros (dio muerte a numerosos personajes y monstruos menores en su camino al reino de Egeo para ser reconocido por éste como su hijo) y culminó tal etapa realizando una hazaña máxima, consistente en enfrentar y dar muerte a una bestia salvaje para convertirse en hombre maduro, ciudadano, héroe, e incluso rey, pues recordemos que a su regreso al Ática, Teseo sucede a su padre en el Trono.

Esta culminación iniciática de dar muerte a una bestia o monstruo está expresada con claridad en la segunda narración plástica en cuestión, la caza del jabalí de Calidón. Esto se constata de manera figurativa en el friso, por ejemplo, en la figura de Peleo, representado como un jovencito imberbe, en segundo plano frente al jabalí; más adelante aparecerá como personaje principal, ya barbado (símbolo de su madurez y edad), en el friso nupcial, lo que revela su posterior conversión en guerrero.

La importancia de esta escena se enfatiza si se suma a lo anterior el hecho de que un héroe no sólo debe iniciarse y destacar en la guerra y en el deporte, sino también en la caza colectiva (considerada más madura que la caza individual), ejercicio que obviamente contribuye a su preparación bélica.

3) El desenvolvimiento del héroe en gestas bélicas y atléticas es crucial en el arquetipo homérico, pues es la manera en que éste obtiene reconocimiento, honor, gloria y fama. En la crátera estudiada, justo en la mitad inferior del cuello, el aspecto bélico está presente en el friso con la lucha entre centauros y lapitas, donde los héroes vencen a la otredad, a lo salvaje, en este caso a los centauros, antimodelos culturales del héroe homérico.

Esta representación se apoya en este vaso por el friso animal que lo recorre por completo en la parte inferior del vientre, y por la representación de la geranomaquia en el pie. El primero de estos frisos alude de manera gráfica a las comparaciones homéricas que se hacen del guerrero atacando al enemigo con un león cazando a su presa. El segundo, despojado del matiz literario cómico que suele atribuírsele (los pigmeos dejan de ser enanos deformes y desproporcionados, y guardan las debidas proporciones de un hombre común en menor escala), es una alusión más, aunque indirecta, a la lucha guerrera contra lo salvaje, encarnado por las grullas, y al estrépito de la batalla, asemejado con el graznido de dichas aves. 
Por otra parte, el aspecto atlético en el vaso está representado por los juegos fúnebres en honor a Patroclo, en los cuales los héroes iliádicos, tomando como pretexto honrar la muerte de su compañero, aprovechan la ocasión para sumar a sus hazañas bélicas sus victorias atléticas, en este caso en la carrera de caballos, que también sirve como entrenamiento para la guerra y para probar su valor y sus capacidades ante sus iguales, ante otros aristócratas-guerreros-atletas.

4) El tópico de la "bella muerte" del héroe homérico, con la que éste obtiene la gloria máxima, la inmortalidad, no física, sino en la memoria de su pueblo, en la memoria de los tiempos, le confiere un sentido cíclico (vida-muerte) al arquetipo del héroe homérico. Y este carácter no podría dejarse de lado en el Vaso François, que, al ser redondo, con esta representación en sus esquemas visuales cierra un círculo, se cierra a sí mismo, en cuanto a temática y en cuanto a forma, relacionando su cuerpo (específicamente el friso con la muerte de Troilo y el ataque a Troya) con sus partes externas, las asas (registros con imágenes de Áyax cargando el cadáver de Aquiles, Ártemis y Gorgo).

El friso con la muerte de Troilo y los sucesos en Troya es parte de los detonadores de la más famosa muerte homérica que se haya predestinado, la de Aquiles, cuyo cadáver, imberbe, es rescatado, en el registro inferior de ambas asas, por Áyax, ambos héroes cobijados bajo la sombra de la muerte, corporeizada en el registro superior de las asas y en la cara interior de la voluta de éstas por las figuras de Ártemis Pótnia y de Gorgo, respectivamente; estas divinidades, más que protectoras del guerrero contra la muerte, en el vaso son regentes de los ciclos de la vida, del ciclo vida-muerte, de la muerte misma, sobre todo del guerrero, del héroe homérico.

5) Todos estos tópicos se desarrollan en el Vaso François, al igual que en la literatura y la cosmovisión homéricas, bajo la intervención divina, por designio de los olímpicos, presentes en la pieza en el friso superior del vientre de uno de sus lados (retorno de Hefesto). Mítica y plásticamente el friso remite al regreso del dios herrero al Olimpo, pero en este contexto, no sólo él es el protagonista, sino también Dioniso, el encargado de traerlo de vuelta. Con la llegada de ambos dioses, el panteón y el poder olímpicos se completan para que bajo su mandato se lleven a cabo todas las acciones humanas, en este caso las heroicas.

Así pues, se puede concluir que, a la luz de un análisis mítico-literario, iconográfico y formal regido por la teoría de la identidad cultural del arte, que plantea relacionar esquemas visuales con esquemas culturales, el Vaso François no es una simple antología mítica seleccionada al azar, sino que fue producto de una cuidada estrategia discursiva dirigida a un fin específico, y posee 
DOI: http://dx.doi.org/10.22201/iie.18703062e.2017.1.2591

$\mathrm{I} 2 \mathrm{O}$

unidad, sentido profundo y un eje temático, el arquetipo del héroe homérico; además de que, en esta pieza, existe una estrecha relación entre la forma del objeto y su contenido.

Resta decir que esta tesis también demuestra que el arte griego, específicamente la cerámica, está abierto a nuevas interpretaciones y enfoques, y puede proporcionar numerosos e interesantísimos temas de estudio, sobre todo para los estudiosos mexicanos de arte, que continuamente buscan temas novedosos con los cuales nutrirse y nutrir a la humanidad. \$ 